\title{
Methods of Measuring Mitochondrial Potassium Channels: A Critical Assessment
}

\author{
Agnieszka Walewska ${ }^{1,+}$, Milena Krajewska ${ }^{1,+}{ }^{\text {, Aleksandra Stefanowska }}{ }^{1,2}{ }^{\mathbb{D}}$, Aleksandra Buta ${ }^{1,2}$, \\ Renata Bilewicz $^{2}{ }^{\mathbb{D}}$, Paweł Krysiński ${ }^{2} \mathbb{D}$, Piotr Bednarczyk ${ }^{3}{ }^{\mathbb{D}}$, Piotr Koprowski ${ }^{1, *}$ and Adam Szewczyk ${ }^{1, *}$
}

check for

updates

Citation: Walewska, A.; Krajewska, M.; Stefanowska, A.; Buta, A.; Bilewicz, R.; Krysiński, P.; Bednarczyk, P.; Koprowski, P.; Szewczyk, A. Methods of Measuring Mitochondrial Potassium Channels: A Critical Assessment. Int. J. Mol. Sci. 2022, 23, 1210. https://doi.org/ $10.3390 /$ ijms 23031210

Academic Editors: Elizabeth Jonas and Qiu-Xing Jiang

Received: 17 November 2021

Accepted: 20 January 2022

Published: 21 January 2022

Publisher's Note: MDPI stays neutral with regard to jurisdictional claims in published maps and institutional affiliations.

Copyright: (C) 2022 by the authors. Licensee MDPI, Basel, Switzerland. This article is an open access article distributed under the terms and conditions of the Creative Commons Attribution (CC BY) license (https:// creativecommons.org/licenses/by/ $4.0 /)$.
1 Laboratory of Intracellular Ion Channels, Nencki Institute of Experimental Biology, Polish Academy of Sciences, 02-093 Warsaw, Poland; a.walewska@nencki.edu.pl (A.W.); m.krajewska@nencki.edu.pl (M.K.); aa.stefanowska@gmail.com (A.S.); abuta@chem.uw.edu.pl (A.B.)

2 Faculty of Chemistry, University of Warsaw, 02-093 Warsaw, Poland; bilewicz@chem.uw.edu.pl (R.B.); pakrys@chem.uw.edu.pl (P.K.)

3 Department of Physics and Biophysics, Institute of Biology, Warsaw University of Life Sciences-SGGW, 02-776 Warsaw, Poland; piotr_bednarczyk@sggw.edu.pl

* $\quad$ Correspondence: p.koprowski@nencki.edu.pl (P.K.); a.szewczyk@nencki.edu.pl (A.S.)

+ These authors contributed equally to this work.

\begin{abstract}
In this paper, the techniques used to study the function of mitochondrial potassium channels are critically reviewed. The majority of these techniques have been known for many years as a result of research on plasma membrane ion channels. Hence, in this review, we focus on the critical evaluation of techniques used in the studies of mitochondrial potassium channels, describing their advantages and limitations. Functional analysis of mitochondrial potassium channels in comparison to that of plasmalemmal channels presents additional experimental challenges. The reliability of functional studies of mitochondrial potassium channels is often affected by the need to isolate mitochondria and by functional properties of mitochondria such as respiration, metabolic activity, swelling capacity, or high electrical potential. Three types of techniques are critically evaluated: electrophysiological techniques, potassium flux measurements, and biochemical techniques related to potassium flux measurements. Finally, new possible approaches to the study of the function of mitochondrial potassium channels are presented. We hope that this review will assist researchers in selecting reliable methods for studying, e.g., the effects of drugs on mitochondrial potassium channel function. Additionally, this review should aid in the critical evaluation of the results reported in various articles on mitochondrial potassium channels.
\end{abstract}

Keywords: mitochondria; potassium channels; patch-clamp; planar lipid bilayer; solid supported membranes; cubic phases

\section{Introduction}

Ion channels are present in all intracellular membranes [1-3]. When compared to plasma membrane channels, functional studies of these channels present new experimental challenges and difficulties. First, purification of intracellular membranes is often necessary before functional studies. Membrane purification is accomplished by well-known techniques, but the high purity of the final preparations poses a considerable challenge. This is especially true when the final functional assay is based on single-channel activity measurements. The limited purity of the final membrane preparations is due to not only the technical limitations of the applied procedure but also in vivo cross-interactions of various intracellular membranes [4]. The continuity of the endoplasmic reticulum with the nuclear membrane is a clear example of such a problem. Second, the unique microenvironment (both functionally and structurally) of intracellular compartments (including mitochondria) affects in vitro studies of various ion channels [5-7]. These issues will be discussed in greater detail later in this paper. 
All of the pitfalls discussed above are observed in functional studies of mitochondrial potassium channels present in inner mitochondrial membranes. Moreover, the density of mitochondrial potassium channels is very low, indicating that they are low-copy-number proteins $[8,9]$. The similarity of the mitochondrial channels to those in the plasma membrane aids in the selection of specific drugs affecting channel activity [10-12]. However, at the same time, researchers must precisely design experiments to ensure that mitochondrial potassium channels, rather than the plasma membrane channels, are studied.

Mitochondria are essential for cellular metabolism and energy production [13]. ATP synthesis is driven by proton motive force across the inner membrane potential playing a major role. The high membrane potential of the inner mitochondrial membrane is the main parameter of efficient ATP synthesis, as described by Peter Mitchell. This property indicates that the inner membrane is an insulator or has low permeability to charged substances. A plethora of inner membrane transporting proteins has been described in the inner mitochondrial membrane [14]. These include anion- and cation-selective ion channels as well as transport proteins that affect membrane potential, such as ATP/ADP translocase $[15,16]$. The following potassium channels were identified in the inner mitochondrial membrane: mitochondrial ATP-sensitive potassium (mitoK $\mathrm{ATP}_{\text {) }}$ channels [17-20], mitochondrial large-conductance calcium-activated potassium ( mitoBK $_{\mathrm{Ca}}$ ) channels [21-23], mitochondrial intermediate-conductance calcium-activated potassium (mitoIK $\mathrm{Ca}$ ) channels [24,25], mitochondrial small-conductance calcium-activated potassium (mitoSK $\mathrm{Ca}_{\text {) }}$ channels [26,27], mitochondrial sodium-activated potassium (mitoSLO2) channels [28], mitochondrial voltage-regulated potassium (mitoKv) channels [29,30], and mitochondrial double-pore potassium (mitoTASK) channels [31,32] (Figure 1). The physiological significance of mitochondrial potassium channels in cell proliferation and death signaling is well documented [5,33-35].

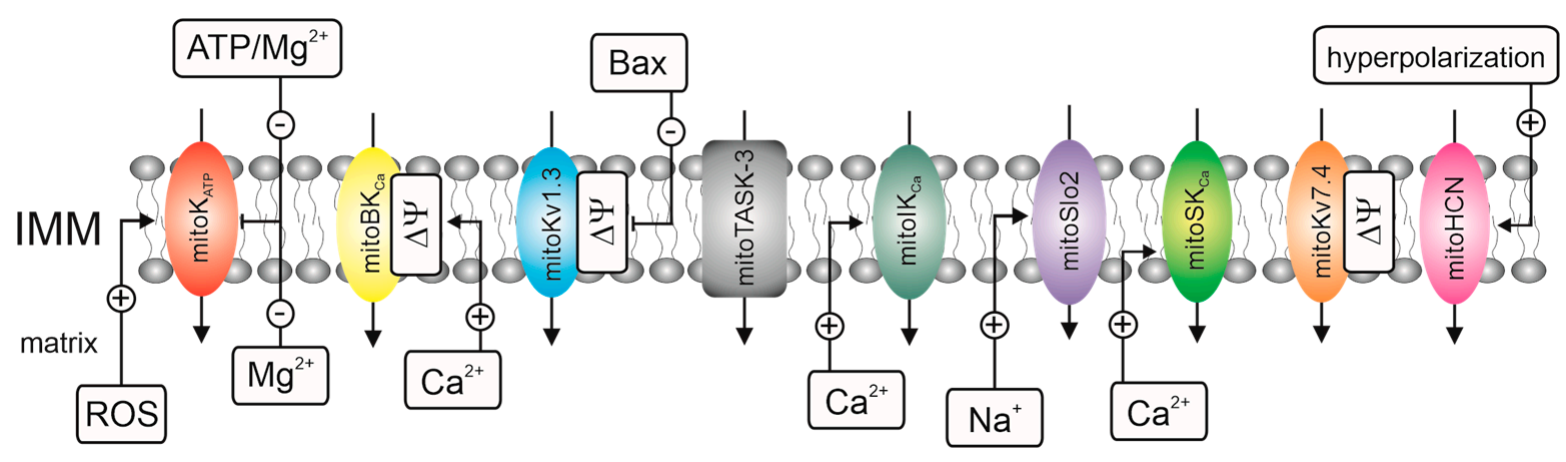

Figure 1. Potassium channels present in the inner mitochondrial membrane with their endogenous

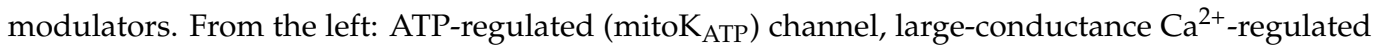
$\left(\right.$ mitoBK $_{\mathrm{Ca}}$ ) channel, voltage-gated (mitoKv1.3) channel, two-pore domain (mitoTASK-3) channel, intermediate-conductance $\mathrm{Ca}^{2+}$-regulated ( mitoIK $_{\mathrm{Ca}}$ ) channel, large-conductance Na-regulated (mitoSLO2) channel, small-conductance $\mathrm{Ca}^{2+}$-regulated (mitoSK $\mathrm{Ca}_{\mathrm{a}}$ ) channel, voltage-gated (mitoKv7.4) channel, and hyperpolarization-activated and cyclic nucleotide-gated (mitoHCN) potassium channel.

Based on biophysical and pharmacological properties, one could claim the similarity of the plasma membrane to mitochondrial potassium channels. In recent years, the molecular identity of mitochondrial potassium channels has been partially established [24,25]. However, some issues have not been clarified and must be studied, including the cytoprotection mechanism induced by mitochondrial potassium channel activation, specific isoforms of mitoBK $_{\mathrm{Ca}}$ channels in various tissues, the identification of mitochondrial auxiliary potassium channel subunits, and the final molecular identification of mitoK ${ }_{\text {ATP }}$ channels [36,37].

The environment in which mitochondrial potassium channels operate differs from that of the plasma membrane. This unique environment concerns both membrane lipids and protein vicinity. It directly affects the basic functions of mitochondrial potassium channels. Additionally, the active role of mitochondria as the site of reactive oxygen species (ROS) 
synthesis differs considerably from that of the plasma membrane. In addition, the protein neighborhood in mitochondria serves as a specific location for mitochondrial potassium channels. For example, it was shown that mitoBK $_{\mathrm{Ca}}$ channels have structural-functional interactions with respiratory chain proteins [38].

Potassium channels in the inner mitochondrial membrane are modulated by inhibitors (blockers) and activators (potassium channel openers) that have been previously described for potassium channels in the plasma membrane. Unfortunately, the majority of mitochondrial potassium channel modulators exhibit a wide range of off-target effects. These include uncoupling properties, respiratory chain inhibition, and effects on cellular calcium homeostasis. Therefore, the correct application of potassium channel inhibitors or activators is crucial in functional studies of intact cells. This important problem has been previously reviewed in detail [12,39-41].

In this paper, we present a critical review of methods used to study the functions of mitochondrial potassium channels. These methods can be classified into three groups:

- $\quad$ Electrophysiological techniques, i.e., the planar lipid bilayer (PLB) technique and patch-clamp technique;

- $\quad$ Flux $\mathrm{K}^{+}$measurements that use fluorescent probes, i.e., small molecule probes, genetically encoded probes, and thallium $\left(\mathrm{Tl}^{+}\right)$-sensitive indicators. We omit flux measurements that use rubidium cations as a tracer for $\mathrm{K}^{+}$. The use of radioactive $86 \mathrm{Rb}^{+}$ and $87 \mathrm{Rb}^{+}$to study mitochondrial potassium channels is uncommon [42] despite the widespread use of $86 \mathrm{Rb}^{+}$to study plasma membrane and intracellular potassium channels [43];

- $\quad$ Biochemical techniques, i.e., the use of unique mitochondrial properties such as swelling, respiration, and high membrane potential to track potassium fluxes via inner membrane channel proteins.

A synopsis of the techniques described in this review can be found in Table 1 . The contribution of these methods for advancing our knowledge on mitochondrial $\mathrm{K}^{+}$channels is quite complex. Electrophysiological techniques such as patch-clamp or PLB allowed characterizing single-channel activities of mitochondrial potassium channels. This helped not only to determine biophysical properties of the channels such as conductance or selectivity but was crucial for describing mitochondrial potassium channel pharmacology. Potassium cation flux measurements with the use of fluorescent probes helped to characterize $\mathrm{K}^{+}$traffic in intact cells. Finally, biochemical techniques contributed to our understanding of the functional role of mitochondrial potassium channels.

At the end of this paper, we will provide some basic information on the potential use of other techniques, such as solid supported membranes or the application of lipid liquid crystalline cubic phases, to study the function of mitochondrial potassium channels. 
Table 1. Overview of methods applied to study mitochondrial potassium channels.

\begin{tabular}{|c|c|c|c|c|}
\hline Technique & Parameters Measured & Advantages & Limitations & References \\
\hline \multicolumn{5}{|c|}{ Electrophysiological Techniques } \\
\hline Planar lipid bilayer & $\begin{array}{l}\text { Current at a controlled voltage } \\
\text { (single-channel conductance, } \\
\text { open probability, channel } \\
\text { activation/inhibition) }\end{array}$ & $\begin{array}{l}\text { Single-channel measurements-high } \\
\text { sensitivity and selectivity, } \\
\text { reconstitution into a defined lipid bilayer, } \\
\text { easy access to both bilayer sides }\end{array}$ & Purity of channel protein preparation & [44-50] \\
\hline $\begin{array}{l}\text { Patch-clamp of the inner } \\
\text { mitochondrial membrane }\end{array}$ & $\begin{array}{l}\text { Current at a controlled voltage } \\
\text { (single-channel conductance, } \\
\text { open probability, channel } \\
\text { activation/inhibition) }\end{array}$ & $\begin{array}{l}\text { Single-channel measurements-high } \\
\text { sensitivity and selectivity, } \\
\text { application to native membranes }\end{array}$ & $\begin{array}{l}\text { Purity of the mitochondria, } \\
\text { nonphysiological } \\
\text { extramembrane environment }\end{array}$ & {$[29,51-57]$} \\
\hline \multicolumn{5}{|c|}{$\mathrm{K}^{+}$Flux Measurements by Fluorescent Probes } \\
\hline Small molecule probes & $\mathrm{K}^{+}$concentration changes & $\begin{array}{l}\text { Simple application } \\
\text { to cell, isolated mitochondria, or liposomes }\end{array}$ & $\begin{array}{l}\text { Limited localization in mitochondria, } \\
\text { poor selectivity for } \mathrm{K}^{+} \text {over } \mathrm{Na}^{+} \\
\text {difficult quantification of absolute }\left[\mathrm{K}^{+}\right] \\
\text {excitation with phototoxic UV-light }\end{array}$ & [58-64] \\
\hline $\mathrm{Tl}^{+}$-sensitive indicators & $\begin{array}{l}\mathrm{Tl}^{+} \text {concentration } \\
\text { changes }\end{array}$ & Nonfluorescent in the absence of $\mathrm{Tl}^{+}$ions & $\begin{array}{l}\text { Low solubility of thallium chloride, } \\
\text { nonspecific subcellular localization }\end{array}$ & [65-70] \\
\hline \multicolumn{5}{|c|}{ Biochemical Techniques } \\
\hline Mitochondrial swelling & Mitochondrial volume & $\begin{array}{c}\text { Simple way of macroscopic ion } \\
\text { flux measurements, } \\
\text { can be measured in fixed cells using } \\
\text { electron microscopy }\end{array}$ & $\begin{array}{l}\text { Only isolated mitochondria, } \\
\text { low selectivity }\end{array}$ & {$[62,63,72,73]$} \\
\hline Respiration & Oxygen consumption & $\begin{array}{l}\text { Tissue, cells, and isolated } \\
\text { mitochondria measurements }\end{array}$ & $\begin{array}{l}\text { Sensitive to nonspecific drug action on } \\
\text { mitochondria or drug } \\
\text { uncoupling properties }\end{array}$ & {$[22,23,53,72,74-76]$} \\
\hline Mitochondrial potential & Potential changes & Cells and isolated mitochondria & $\begin{array}{l}\text { Sensitive to nonspecific action } \\
\text { on mitochondria }\end{array}$ & {$[22,23,53,74-77]$} \\
\hline
\end{tabular}




\section{Reconstitution of Mitochondrial $\mathrm{K}^{+}$Channels into Planar Lipid Bilayers}

The planar lipid bilayer (PLB) technique, also known as the black lipid membrane (BLM) technique, was first described by Muller in 1962 [78]. This well-established method has been extensively used in recent decades to study a plethora of ion channels, including those found in intracellular membranes $[44,45]$. This is due to the inherent characteristics of the PLB technique. First, an artificial lipid membrane is formed across a small diameter $(150$ to $250 \mu \mathrm{m})$ cavity in a sheet of Teflon, Delrin, or polystyrene. Next, a suspension of channel-containing membrane vesicles is added and, after the ion channel is spontaneously incorporated into the lipid bilayer, the ion flow is measured as the change in current over time. The PLB technique has been used to identify and characterize mitochondrial channels from various tissues and organisms [39] (Figure 2). In this case, mitochondria are isolated, and submitochondrial particles (SMPs) are prepared by exposing the mitochondria to ultrasound or osmotic shock. In the next step, SMPs are fused to artificial membranes. The activity of the mitochondrial ATP-sensitive potassium (mitoK $\mathrm{ATP}_{\text {) }}$ channel from cardiac mitochondria has been intensively studied [46-49].

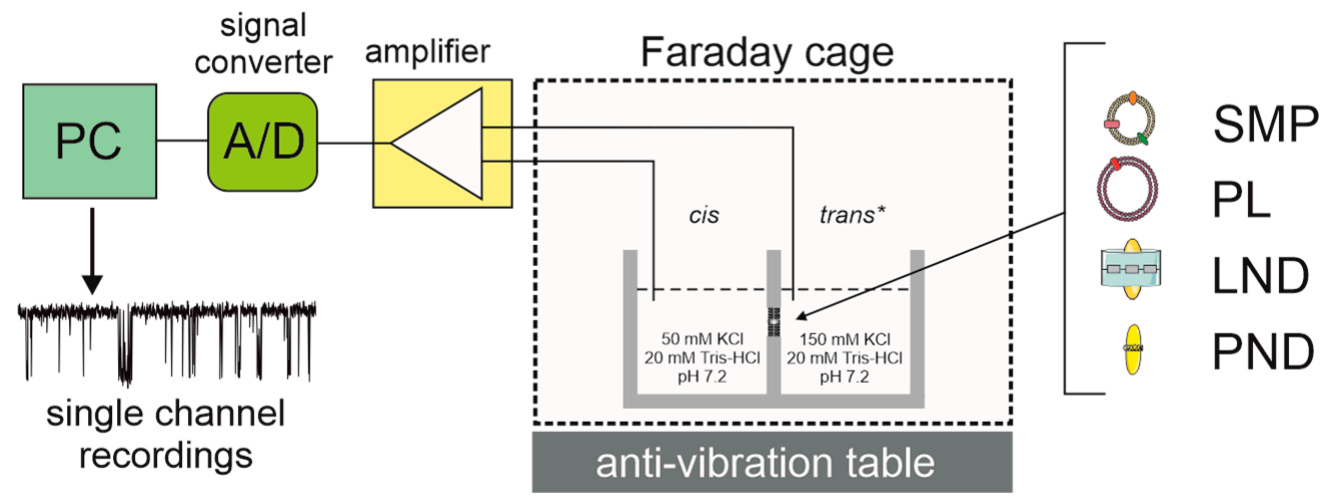

Figure 2. Planar lipid bilayers (PLBs) were used to record mitochondrial $\mathrm{K}^{+}$channel activity. The main PLB equipment includes a personal computer (PC) with software, a signal converter (A/D), an amplifier, a Faraday cage, an antivibration table, and a holder with separate cis and trans compartments (*-grounded site). Alternative systems to incorporate channels to PLB include: SMPsubmitochondrial particles, PL-proteoliposomes, LND—lipid nanodiscs (MSP1- and SMA-based nanodiscs), and PND—peptidiscs (peptide-based nanodiscs).

The ability to record channel activity on a single-molecule level under fully controlled conditions distinguishes the PLB technique from the patch-clamp technique. It should be noted that the lipid environment in PLB is artificial and different lipid environments can impact channel gating behavior. Usually, in PLB experiments lipid bilayers are formed with soybean asolectin due to its low price, ease in forming bilayers, and complex lipid composition [20,36]. Soybean asolectin contains phosphatidylcholine (PC), phosphatidylethanolamine (PE), and phosphatidylinositol (PI), each accounting for ca. 25\% of total lipids, along with minor amounts of other phospholipids, which is significantly different from the lipid content of IMM. PC and PE are still the most abundant phospholipids in the IMM, comprising up to $75 \%$ of total lipids. However, the third most abundant and the most unique lipid for IMM is cardiolipin (CL) which makes up about 15-20\% of the total phospholipids. Minor lipids are phosphatidylserine (PS), 3\%, and PI, 5\% [79]. The PLB technique is particularly useful for investigating the role of lipid constituents in channel gating, and in the case of mitochondrial channels it would be favorable to mimic the specific lipid environment of the IMM. However, the impact of the specific lipid environment of the IMM on potassium channels has not been studied to date. The PLB technique also provides easy access to both sides of the channel after incorporation, which allows for investigating the topology of ion channel-drug binding. Due to these qualities of the PLB technique, properties of the cardiac mitoK $\mathrm{ATP}_{\mathrm{P}}$ channel, such as the ATP, $\mathrm{pH}$, or $\mathrm{Mg}^{2+}$ regulation, have been reported [46,47]. One serious drawback associated 
with the identification of mitochondrial channels by PLB measurements is the purity of the mitochondrial fraction. Because PLB recordings have a single-molecule resolution, even minor contamination could lead to false conclusions. Similarly, the use of SMPs does not allow for molecular identification of channel proteins based on electrophysiological activity due to their multiprotein composition. However, advances in protein purification, including the introduction of new detergents, aid in identifying the molecules responsible for well-known mitochondrial channel activities. In this way, ATP synthase was purified to near homogeneity, and it was shown that ATP synthase dimers, but not monomers, are responsible for the so-called "megachannel" activity [80]; using a similar technique, however, it was shown that monomeric ATP synthase also formed the same "megachannel" activity [81]. As an alternative, complementary, e.g., biochemical, methods could be used to identify molecular candidates for mitochondrial channels, and the electric activity of recombinant purified proteins could then be tested in PLBs. The CCDC51 protein was proposed based on its mitochondrial localization and topology as a pore constituent of the mitoK ${ }_{\text {ATP }}$ channel and renamed MITOK. Recombinant MITOK-6xHIS protein was expressed either in Escherichia coli or by coupled in vitro transcription/translation, purified, and reconstituted in liposomes, and its electric activity was detected and characterized in PLBs [36].

In recent years, nanodisc technology has revolutionized membrane protein science [82]. All nanodiscs are soluble fragments of lipid bilayers (lipid nanodiscs (LNDs)), but the way these membrane fragments are stabilized may differ. Thus, there are two main types of nanodiscs: those made of belt proteins, such as membrane scaffold protein (MSP) derivatives [83], and those made of amphipathic copolymers, such as styrene-maleic acid (SMA) [84]. In addition to lipid nanodiscs, which contain membrane fragments, membrane proteins could be stabilized in solution by amphipathic peptides, which form so-called peptidiscs (peptide nanodiscs (PNDs)) without the involvement of detergents and lipids $[85,86]$. However, to date, PNDs have not been used to deliver channels into PLBs.

To incorporate membrane proteins into MSP nanodiscs, proteins from native membranes must be solubilized and reconstituted into self-assembling MSP nanodiscs [87]. However, membrane proteins can also be directly incorporated into MSP nanodiscs during translation. For instance, viral ion channels have been incorporated into MSP nanodiscs during coupled in vitro transcription/translation reactions and then efficiently transferred into a PLB, allowing recording of ion channel activity [88]. This approach allows for the study of proteins while also providing a fast, reliable, and contamination-free method for the functional analysis of ion channels, eliminating the need to obtain material from living cells.

Amphipathic copolymers such as SMA exhibit detergent-like properties and can form nanodiscs via direct membrane solubilization without the use of detergents. Therefore, SMA nanodiscs are often referred to as "native nanodiscs" [89]. SMA was used to solubilize yeast mitochondrial respiratory complex IV, showing that large membrane protein complexes could be stabilized within these particles [90]. Moreover, artificial mitochondrial membranes could be formed within SMA nanodiscs [91]. Despite the potential benefits of nanodiscs, only one potential mitochondrial channel isoform, ROMK2, expressed in Escherichia coli cells, has been investigated with this technology [50]. In this study, channel activity was observed more often when the ROMK2 channel was reconstituted in nanodiscs than when it was reconstituted into proteoliposomes before adding to PLBs, suggesting an advantage of nanodisc technology.

In conclusion, the well-established PLB technique currently provides a fully controlled environment (both in terms of protein and lipid composition) for the reconstitution of multi-subunit mitochondrial potassium channels, indicating further use of this technique in the future. 


\section{Patch-Clamp of the Inner Mitochondrial Membrane}

The patch-clamp technique was developed by Erwin Neher and Bert Sakmann more than 40 years ago [92,93] and is currently one of the most important electrophysiological methods for recording the activity of ion channels in their native environment. The patchclamp technique has been modified to study ionic currents in tissue sections [94]; organelles such as lysosomes [95,96], mitochondria [38,51,97], and nuclei [98,99]; and bacteria [100,101].

One specific application of the patch-clamp technique is the recording of the electric activity of ion channels and transporters residing in the inner mitochondrial membrane, which was pioneered by Sorgato et al. [97] and quickly followed by Petronilli [51]. With the patch-clamp technique, mitochondrial potassium channels were discovered in human bronchial epithelial cells [52], skin fibroblasts [53], cardiomyocytes [54], endothelial cells [23], keratinocytes [55], astrocytomas [38], and lymphocytes [29]. Thanks to this technique, many different types of channels have been discovered in the inner mitochondrial membrane, including potassium channels inhibited by ATP (mitoK $\left.{ }_{\text {ATP }}\right)[56,57]$, intermediate-conductance calcium-regulated potassium channels (mitoIK $\mathrm{Ca}_{\mathrm{a}}$ ) [24], largeconductance calcium-activated potassium channels (mitoBK $\mathrm{Ca}_{\mathrm{a}}$ [21], and mitochondrial megachannels (also known as permeability transition pores) (mPTP) [102] (Figure 3). The most important advantage of the patch-clamp technique is the ability to record the activity of ion channels in their native environment, namely, in the inner mitochondrial membrane. In addition, this technique enabled researchers to investigate the regulation of mitochondrial ion channel activity by various substances (natural origin as well as synthetic modulators of channel activity). New regulatory mechanisms of the activity of mitochondrial ion channels have been discovered. For instance, it has been shown that mitoBK $_{\mathrm{Ca}}$ channels are regulated by membrane stretch [103], gasotransmitters [34], or the natural flavonoids naringenin [104] and quercetin [105]. Due to the above-mentioned advantages and relatively high frequency of recording channel activity, patch-clamp of the IMM appears to be a convenient technique for studying mitochondrial ion channels and is recognized as the gold standard. Therefore, the potential drawbacks of this technique determine the quality of the data and the advancements of the research field.

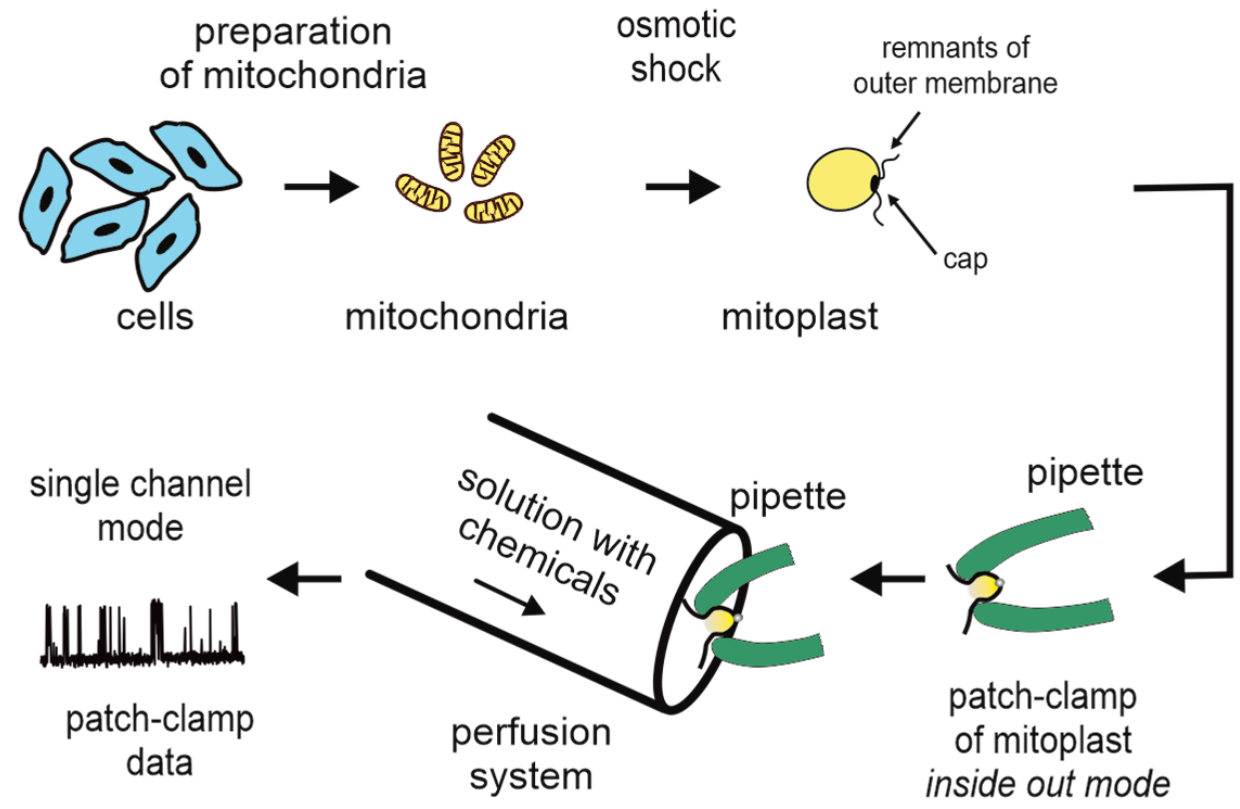

Figure 3. Patch-clamp technique in mitochondrial $\mathrm{K}^{+}$channel studies. Schematic representation of the preparation of mitochondria and mitoplasts and the patch-clamp experiment in inside-out mode with a perfusion system.

A patch-clamp technique variant that uses a concentric electrode arrangement in which an external pipette protects an inner patch pipette during plasma membrane pen- 
etration, after which a seal can be formed on an internal organelle membrane, e.g., a mitochondrial membrane, has previously been described [106]. However, this technique is complicated [107]. Therefore, to study the activity of mitochondrial channels by patchclamp, mitochondria must be isolated. In general, freshly isolated mitochondria are used; therefore, the time spent on their isolation is kept to a minimum, and simple differential centrifugation is used to obtain the mitochondria-enriched fraction [108]. However, in some studies, an additional Percoll gradient purification step was added to increase mitochondrial purity [28]. Mitochondria are surrounded by two membranes: a smooth outer membrane (OMM) and a folded inner mitochondrial membrane (IMM). To record channel activity from the IMM, the OMM is disrupted using hypoosmotic shock to form mitoplasts. Mitoplasts are recognized as transparent circular objects with characteristic dark caps formed by OMM remnants that are visible under a phase-contrast microscope. The rest of the method is straightforward. After capturing a mitoplast with a recording pipette under negative pressure (suction) and gigaohm seal formation, a membrane patch either forms spontaneously at the tip of the pipette or is excised by tapping the pipette holder. Thus, all that is left to do is record the channel activity. However, when patching mitoplasts, the first source of uncertainty is the purity of the isolated mitochondria and the choice of vesicles identified as mitoplasts among other cellular debris. Despite its characteristic shape and cap, distinguishing a mitoplast from other objects may be challenging for inexperienced researchers. Mitochondria containing DNA (mtDNA) allowed for the development of a single-mitoplast PCR assay [74], which can confirm that the selected object is a mitoplast. In this assay, a single intact mitoplast was aspirated by a glass pipette with a tip large enough to accommodate the mitoplast and was then transferred into a PCR tube. To detect mtDNA, PCR with primers that can specifically amplify a fragment of mtDNA was used. The separation and visualization of the PCR product by standard agarose gel electrophoresis proves that the acquired vesicle was a mitoplast. In this way, the correct objects can be selected for the patch-clamp technique, despite the presence of cellular debris that remains after mitochondrial isolation. In a more direct approach, mitochondria can be labeled with a fluorescent protein (e.g., YFP) that is specifically targeted to mitochondria [109] or loaded with a mitochondria-specific fluorescent dye (e.g., MitoTracker) that is trapped inside mitochondria during purification and swelling [77]. Then, fluorescent mitoplasts can be selected under a fluorescence microscope during the patch-clamp experiment. This direct method appears to be the most advantageous for identifying the correct object-the mitoplast.

However, even these methods cannot guarantee that the activity of channels from the IMM is recorded. It is assumed that the unique mitoplast morphology is due to the expansion of the folded IMM, the rupture of the OMM, and the disintegration of the remaining intracellular organelles. Interestingly, mitochondria have a molecular relationship with the endoplasmic reticulum (ER), which results in the presence of mitochondria-associated membranes (MAMs). It has been shown that in cells subjected to hypotonic shocks, all organelles were fragmented and swollen into vesicles [110]. However, at the same time, interorganellar contacts were preserved, allowing vesicle pairs of swollen mitochondria and MAMs to be observed. It is therefore plausible that MAMs rather than IMMs could be patched. For instance, based on subcellular fractionation, ryanodine receptors (RyRs) were assumed to be present in IMMs, and their supposed mitochondrial localization was supported by confocal microscopy [111]. Mitochondrial localization of RyRs was further favored by patch-clamp recordings on mitoplasts [112]. In these recordings, only $1.1 \%$ of patches had RyR channel activity. However, Noterman et al. [113], based on an improved mitochondrial fractionation protocol, recently ruled out the presence of RyRs in mitochondria. It can therefore be speculated that the small number of RyR channels active in membrane patches derived from objects identified as mitoplasts were, in fact, present not in IMMs but in MAMs.

What are some possible solutions to such ambiguities? First, patch-clamp experiments could be carried out not only in the excised-patch configuration but also in the wholemitoplast configuration $[109,114]$. In this way, all the activities present in the vesicle are 
recorded, and single channels that "get in the way" and are interpreted as mitochondrial are not counted. Second, in the excised-patch configuration, characteristic channel activity found only in mitochondria can be used as an internal standard. This type of activity, i.e., mitochondrial megachannel, was identified in early patch-clamp studies on mitoplasts [102]. The pharmacology of the mitochondrial megachannels is well known [115,116], and current research suggests that ATP synthase dimers or monomers might be the main molecular component [82,117]. Because megachannels can be activated or inhibited by several compounds [118] and detected in the majority of IMM patches [119], their activity can be correlated with the activity of a channel under investigation. To our best knowledge, only Szabo et al. [29] used megachannel activity induced by the addition of $0.1 \mathrm{mM} \mathrm{Ca}^{2+}$ as a marker of IMM for establishing mitochondrial localization of the Kv1.3 channels.

The next disadvantage of patch-clamp recordings, whether in the excised-patch or the whole-mitoplast configuration, is that the inner mitochondrial membrane is disrupted during patch formation, resulting in the loss of soluble mitochondrial matrix components. To mitigate this phenomenon, one can use a perforated-patch configuration [120]. However, no studies on mitoplasts in this configuration have been carried out.

Despite the problems mentioned above, patch-clamp of the inner mitochondrial membrane is a unique approach for studying ion channel activity that has significantly contributed to the advancement of the field of mitochondrial potassium channels.

\section{4. $\mathrm{K}^{+}$-Specific Fluorescent Indicators in Mitochondrial Potassium Channel Studies}

Reconstitution of mitochondrial potassium channels into PLBs and mitoplast patchclamp experiments both require cell disruption and mitochondria purification. This is followed by the preparation of mitoplasts (in case of patch-clamp) or submitochondrial particles (in case of channel reconstitution into planar lipid bilayers). All these procedures introduce the methodological difficulties mentioned in previous sections. Hence, techniques for measuring mitochondrial potassium ion (and other alkali metal ion) trafficking have been intensively investigated for many years $[58,59]$ with help of fluorescent indicators. Unfortunately, most of these fluorescent indicators suffer from limited specificity for $\mathrm{K}^{+}$, low dynamic range, difficulty of loading into cells, no selective targeting to mitochondria, and toxicity.

The optimal mitochondrial $\mathrm{K}^{+}$sensor should have a dynamic range compatible with the intracellular $\mathrm{K}^{+}$concentrations, i.e., $50-150 \mathrm{mM}$ in different cell compartments. Additionally, it should be insensitive to $\mathrm{pH}$ and millimolar $\mathrm{Na}^{+}$concentrations. Finally, it should be located in the mitochondrial matrix. This final property can be obtained relatively easily by attaching a lipophilic triphenylphosphonium cation $\left(\mathrm{TPP}^{+}\right)$to the sensor. Because of the negatively charged mitochondrial interior, sensors with $\mathrm{TPP}^{+}$moiety will efficiently accumulate in the mitochondrial matrix.

Several small-molecule fluorescent $\mathrm{K}^{+}$sensors have been developed to image $\mathrm{K}^{+}$ fluctuations using fluorescence microscopy [110]. The most well known $\mathrm{K}^{+}$sensors for biological studies are based on crown ethers and include potassium-binding benzofuran isophthalate (PBFI) and its cell-permeable form bis(acetyloxymethyl) esterified PBFI (PBFIAM), as well as Asante Potassium Green-1 (APG-1) [60,61]. Unfortunately, these probes suffer from poor selectivity for $\mathrm{K}^{+}$over $\mathrm{Na}^{+}$and difficult quantification of absolute $\left[\mathrm{K}^{+}\right]$and require excitation with phototoxic UV-light. Hence, PBFI was used to study the function of mitochondrial ATP-regulated potassium (mitoK $\mathrm{ATP}_{\mathrm{A}}$ ) channels in well-defined conditions following liposome reconstitution [62]. The same probe was used to study mitoBK $\mathrm{Ca}$ activity in isolated cardiac mitochondria [63]. Interestingly, intracellular $\mathrm{K}^{+}$fluxes were also measured in cultured hippocampal neurons by using PBFI to better understand the role of $\mathrm{K}^{+}$in neuronal death under ischemic conditions [121].

A fluorescent $\mathrm{K}^{+}$sensor targeted to mitochondria was produced by attaching $\mathrm{TPP}^{+}$to triazacryptand-modified 3-styrylated BODIPY and designated KS6 [122]. It was found to be insensitive to $\mathrm{pHs}$ in the range of 5.4 to 9.0 as well as other metal cations. Localization of this probe was observed in the mitochondria of HeLa and U87MG cells [122]. A new 
mitochondrial-targeted $\mathrm{K}^{+}$probe based on crown ethers, known as NK1, was recently synthesized [123]. NK1 has a good response to $\mathrm{K}^{+}$but a poor response to $\mathrm{pH}$ changes and other metal cations and was used to measure $\mathrm{K}^{+}$fluxes in the mitochondria of living cells. However, the fluxes measured by KS6 and NK1 were induced by ionophores (nigericin or ionomycin). Hence, both probes must be tested under more physiological conditions. Recently, the first near-infrared (NIR) fluorescent mitochondrial-targeted $\mathrm{K}^{+}$probe was developed [124]. This probe contained a rhodamine analog as the fluorophore and triazacryptand as the $\mathrm{K}^{+}$-binding moiety. The efflux of $\mathrm{K}^{+}$from mitochondria during apoptosis was reported by using this probe, taking advantage of the unique properties of the probe: a large Stokes shift $(120 \mathrm{~nm})$ and a long emission peak wavelength at $720 \mathrm{~nm}$ [124]. It should be noted that $\mathrm{K}^{+}$flux may affect mitochondrial membrane potential and, as a result, the accumulation of the $\mathrm{TPP}^{+}$-conjugated probes. Therefore, carefully designed experimental schemes should be employed to avoid potential errors.

The use of thallium cations as $\mathrm{K}^{+}$surrogates with $\mathrm{Tl}^{+}$-sensitive fluorescent indicators appears to be especially useful in functional studies of potassium channels. Because the ionic radii of $\mathrm{Tl}^{+}(0.154 \mathrm{~nm})$ and $\mathrm{K}^{+}(0.144 \mathrm{~nm})$ are similar, $\mathrm{Tl}^{+}$is conducted by $\mathrm{K}^{+}$ channels [125]. The cells are loaded with nonfluorescent, thallium-specific dye while thallium ions flow through open potassium channels. Thallium cations bind the dye, generating a fluorescent signal proportional to channel activity. Benzothiazole coumarin acetoxymethyl ester (BTC-AM) is a $\mathrm{Tl}^{+}$-sensitive fluorescent indicator that is known as a ratiometric $\mathrm{Ca}_{2}^{+}$sensor but is also sensitive to $\mathrm{Tl}^{+}$with different spectral characteristics, preventing signal overlap between these sensitivities. To measure the $\mathrm{Tl}^{+}$-BTC complex, its fluorescence is excited at $\lambda_{\mathrm{ex}}=488 \mathrm{~nm}$, and emission is monitored at $\lambda_{\mathrm{em}}=525 \mathrm{~nm}$ [65]. This assay was used to study the properties of mitoK ATP [66] and mitoBKCa channels [67] in isolated mitochondria. BTC-AM and another dye with similar properties, Fluozin-2$\mathrm{AM}$ [60], were used by Foster et al. [68] to measure mitochondrial $\mathrm{Tl}^{+}$transport via the ROMK2 channel in permeabilized cells. BTC and Fluozin-2 did not accumulate specifically in mitochondria, and before Foster's study [68] the latter was used only in high-throughput screening for small molecule inhibitors of plasma membrane-localized ROMK channels [69]. To measure mitochondrial $\mathrm{Tl}^{+}$transport, cells were first loaded with BTC-AM or Fluozin-2$\mathrm{AM}$. Next, before the $\mathrm{Tl}^{+}$assay, cells were treated with digitonin to permeabilize the plasma membrane, resulting in the loss of the cytosolic component of dye and leaving only the mitochondrial compartment loaded with the indicator. This protocol has previously been used to preferentially localize the above-mentioned PBFI indicator to the mitochondria [64].

One serious disadvantage of using $\mathrm{Tl}^{+}$is the low solubility of thallium chloride (approximately $4 \mathrm{mM}$ ), which requires the use of chloride-free solutions. However, a commercially available fluxOR assay based on the same principle but with the fluxOR dye, which is approximately 10 -fold more sensitive to thallium than BTC, requires much lower thallium concentrations [70]. This also means that the assay can be carried out in physiological, normal-chloride saline. Unfortunately, the fluxOR assay has never been used in mitochondrial studies.

Several genetically encoded Förster resonance energy transfer (FRET)-based $\mathrm{K}^{+}$indicators have recently been developed [71,126]. It was shown that these indicators could be successfully used for $\mathrm{K}^{+}$fluorescence imaging, which may improve the understanding of intracellular $\mathrm{K}^{+}$signaling pathways. Notably, Bischof et al. [71] designed a genetically encoded potassium ion indicator (GEPII) that was targeted to various intracellular compartments, including mitochondria, and revealed lower $\mathrm{K}^{+}$concentrations $\left(\left[\mathrm{K}^{+}\right]\right)$within mitochondria compared to $\left[\mathrm{K}^{+}\right]$in the cytoplasm of living cells. Finally, GEPII was used to monitor subcellular $\mathrm{K}^{+}$dynamics during cell depolarization by low extracellular $\left[\mathrm{K}^{+}\right]$. During such treatment, $\left[\mathrm{K}^{+}\right]$in cytoplasm decreased while in mitochondria the low $\left[\mathrm{K}^{+}\right]$ gradually increased. Despite these interesting data, the application of these probes to study the function of mitochondrial potassium channels has not yet been demonstrated. 


\section{Biochemical Methods for Studying Mitochondrial $\mathrm{K}^{+}$Channels}

Due to the unique properties of mitochondria, it is possible to study $\mathrm{K}^{+}$influx via mitochondrial channels by measuring mitochondrial parameters such as swelling, mitochondrial potential, respiration rate, and mitochondrial ROS synthesis.

Under physiological conditions, mitochondrial volume is regulated by the potassium cycle, i.e., by $\mathrm{K}^{+}$influx and $\mathrm{K}^{+}$efflux via the $\mathrm{K}^{+} / \mathrm{H}^{+}$antiporter [127]. A slight increase in matrix volume stimulates mitochondrial metabolism through a variety of complex mechanisms [128,129]. Potassium is the most abundant monovalent cation in the cytoplasm, and it mediates changes in volume when the $\mathrm{K}^{+}$conductance of the inner membrane is increased. It has been known for some time that mitochondria may swell in response to valinomycin. This phenomenon is used to measure the activity of mitochondrial potassium channels in isolated mitochondria. The main method for estimating mitochondrial volume is to measure the absorbance of isolated mitochondrial suspensions at $520 \mathrm{~nm}$. Light absorbance decreases with mitochondrial swelling. This kind of simple assay has previously been used to identify the basic properties of mitoK $\mathrm{ATP}_{\mathrm{AT}}$ [72] and mitoBK $\mathrm{Ca}_{\mathrm{Ca}}$ channels [63].

The mitoK $\mathrm{K}_{\text {ATP }}$ channel in brain mitochondria was identified by using the swelling technique [72]. To clarify the role of mitoK $\mathrm{ATP}_{\mathrm{P}}$ in cardioprotective changes in mitochondrial matrix volume, the relationships among mitoK $_{\mathrm{ATP}}$, protein kinase, $\mathrm{ROS}$, and mitochondrial permeability transition were measured [73]. The volatile anesthetic sevoflurane increased

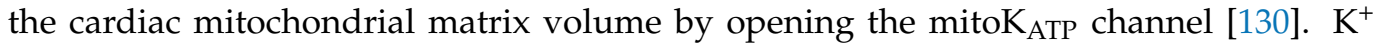
fluxes through cardiac mitoBK $\mathrm{Ca}_{\mathrm{a}}$ channels in the presence of the potassium channel opener NS11021 were studied with light scattering [63].

The mitochondrial swelling method is a simple method, but the final results depend on the complex phenomena of inner mitochondrial membrane permeability, which could be the result of many ion transport pathways being activated. This may cause issues with data misinterpretation by involving specific mitochondrial potassium channels. Moreover, excessive matrix swelling upon calcium ion accumulation occurs because of mitochondrial permeability transition pore ("megachannel") activation. This process does not involve mitochondrial potassium channels. Hence, we do not recommend this technique for measuring the activity of mitochondrial potassium channels. Complex analysis of the mitochondrial swelling phenomenon has been reviewed recently [131].

$\mathrm{K}^{+}$influx into the mitochondrial matrix is driven by the membrane potential and negatively charged mitochondrial matrix. Hence, mitochondrial potential measurements could be used to track mitochondrial $\mathrm{K}^{+}$channel activity. The influx of $\mathrm{K}^{+}$leads to mitochondrial depolarization, i.e., a decrease in membrane potential. Fluorescent probes such as tetramethylrhodamine methyl ester (TMRM) or ethyl ester (TMRE) are used to measure mitochondrial potential. Depolarization induced by the potassium channel opener NS11021 activating mitoBK $\mathrm{Ca}_{\mathrm{a}}$ in cardiac mitochondria was observed with a TMRM probe [63]. A TMRE probe was used to observe changes in mitochondrial membrane potential due to activation mitoSK $_{\mathrm{Ca}}$ channels [77]. The use of fluorescent probes is relatively simple, easy, and useful if the changes in membrane potential are relatively large, which is not obvious given the low density of potassium channels in the inner mitochondrial membrane. $\mathrm{TPP}^{+}$ ion-selective electrode is another way to measure changes in membrane potential when used with the isolated mitochondria. This kind of ion-selective electrode was applied to show amoeba [75] and fibroblast [54] mitochondria depolarization due to mitoK ${ }_{\mathrm{ATP}}$ channel activation. Using the same method, depolarization because of mitoBK $\mathrm{Ca}_{\mathrm{a}}$ channel activation was observed in potato [22], endothelial [23], Dictyostelium discoideum [76], and dermal fibroblast [74] mitochondria. It is important to remember that these kinds of measurements can only be performed on isolated mitochondria.

Mild potassium uncoupling due to $\mathrm{K}^{+}$influx may increase mitochondrial respiration, as observed with the use of classical protonophoric uncouplers. This kind of observation has been reported for a variety of mitochondrial $\mathrm{K}^{+}$channels [54,74]. When mitochondrial channel activation is induced by potassium channel openers, it is critical to show that the increase in mitochondrial respiration has ion selectivity or is inhibited by selective 
channel blockers. Possible protonophoric uncoupling properties can be ruled out by single patch-clamp recordings.

Due to mild uncoupling caused by $\mathrm{K}^{+}$influx, a decrease in mitochondrial ROS synthesis upon channel activation may also be observed [132]. Interestingly, depolarization of mitochondrial potential due to channel activity may cause an increase in delta $\mathrm{pH}$ on the inner mitochondrial membrane [133].

Biochemical studies are useful to characterize mitochondrial potassium channel functions. They help for example to correlate single-channel properties with observations on channel activity related only to mitochondria function such as respiration or high membrane potential. However, there are many disadvantages. For example, mitochondrial depolarization caused by certain drugs could be due to not only the increased influx of $\mathrm{K}^{+}$, but also inhibition of the mitochondrial respiratory chain or uncoupling properties of the applied drug. An increase in mitochondrial respiration could be due to $\mathrm{K}^{+}$influx, but it could also be due to the protonophoric properties of the applied drug. In conclusion, biochemical assays for studying mitochondrial $\mathrm{K}^{+}$channel activity are only useful when used in a comprehensive set of experiments.

\section{Future Membrane Models: Cubic Phases and Solid Supported Membranes}

Planar lipid bilayers and patch-clamp techniques described above provide valuable information on the activity of mitochondrial $\mathrm{K}^{+}$channels. The possibility to follow and control single-channel properties is unparalleled. However, there are many disadvantages, such as the randomized orientation of reconstituted channels (PLB), or difficulties in approaching the specific channel, and gigaohm seal formation in the patch-clamp technique. The most pronounced problem is the inherent fragility of the applied membranes, precluding long-term experiments. Additionally, since these techniques rely on a singlemolecule approach, individual experiments cannot be converted into the membrane sensing platforms for larger-scale functional studies of drug interactions with mitochondrial $\mathrm{K}^{+}$ channels or application in robust analytical devices. To overcome these difficulties, lipid matrices of various topology and geometries can be deposited directly on conducting substrates (electrodes) $[134,135]$. In such a way, a more stable experimental system can be prepared for the reconstitution of ion channels. Such biomimetic membranes can be investigated using a variety of techniques to describe a structure-function relationship of the embedded membrane proteins: spectroscopic and microscopic techniques including atomic force microscopy or quartz crystal microbalance. Additionally, electrochemistry approaches such as impedance spectroscopy for the evaluation of membrane defectiveness and characterization of membrane capacitive and resistive properties can be applied. This would allow also determining the amount of channel protein reconstituted into the membrane. Here, we will describe the lipidic cubic phase and lipid bilayer solid supported membranes as a potential host for mitochondrial potassium channels in the future.

\subsection{Lipid Cubic Mesophases as Membranes for Embedding Potassium Channels}

Lipid cubic phases (LCPs) consist of a single, continuous lipidic bilayer that forms two interpenetrating but unconnected water networks (Figure 4); they are a promising environment for the reconstitution of membrane proteins that are generally not stable outside of cell membranes but can be stabilized by entrapment in a matrix that resembles a natural environment. Their unique amphiphilic nature allows for the accommodation of hydrophilic substances within aqueous channels, and hydrophobic membrane proteins within the lipid bilayer.

Lipid cubic mesophases coexist with excess water over a wide temperature range and have a flexible structure that can adapt to accommodate the protein. Appropriate amphiphilic compounds with large hydrophilic headgroups such as $n$-octyl- $\beta$-D-glucopyranoside are added to increase the aqueous channel sizes for the incorporation of integral membrane proteins with larger extracellular domains. Reversed cubic phases and nanostructured biomimetic materials have been successfully used for the crystallization of several mem- 
brane proteins [136-141]. LCP technologies for structural studies of membrane proteins such as bacteriorhodopsin or gramicidin were described by Cherezov et al. [142]. The so-called cubicon method for concentrating membrane transporter proteins was described by Ma et al. [143]. The organization of proton pumps and lipids in cubic mesophase crystals was described by Belrhali et al. [144].

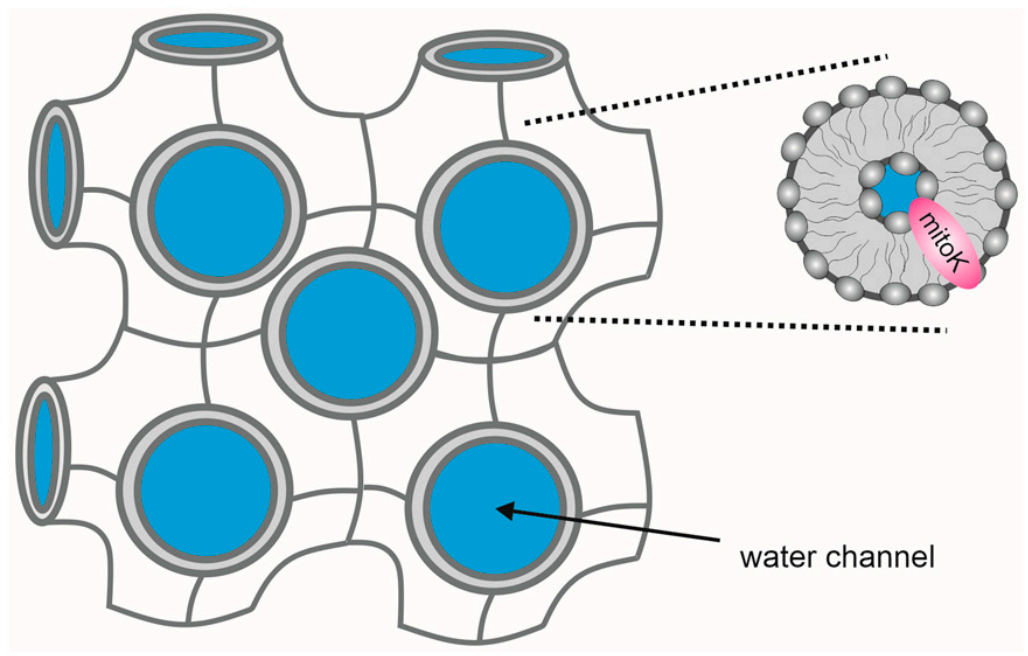

Figure 4. The lipidic liquid crystalline cubic phase (LLC) includes a curved bicontinuous lipid bilayer extending in three dimensions and surrounds two interpenetrating but noncontacting aqueous nanochannels. This double-diamond cubic phase with Pn3m space group shown above is promising for stabilizing membrane proteins and studying their function. Mitochondrial potassium channels could be embedded in the LLC, with their hydrophobic domains incorporated in the lipid bilayer and extramembranous domains exposed to aqueous channels.

LCPs are useful not only for crystallizing membrane proteins and evaluating their structures but also for investigating their properties and functions. For instance, reconstitution and demonstration of enzymatic activity of fructose dehydrogenase (FDH), a membrane-bound redox enzyme, in monoolein LCP was reported [145]. In a spectrophotometric study, it was confirmed that, compared to its behavior in monolinolein-based LCP solutions, in meso immobilized FDH has improved stability [146]. In a recent study, it was shown for the first time that the $\mathrm{Na}^{+} / \mathrm{K}^{+}$-ATPase retained activity when reconstituted in the GMO-based LCP [147]. The reconstitution of bacterial ClC exchanger from Escherichia coli in an LCP was described [148], and the efficiency of chloride transport was studied by placing the cubic phase in a lipid membrane device. Active gating in an LCP was described for the glucose transporter protein Staphylococcus epidermidis (GlcPSe). Glucose diffusion was tuned by an independent physiological stimulus: the $\mathrm{pH}$ gradient [149]. The function of membrane proteins, such as the light-driven bacteriorhodopsin, accommodated in LCPs was also measured $[150,151]$. Gramicidin dimer crystallization in the cubic mesophase was described [134], and the influence of the lipid used for LCP was investigated [152]. Research into X-ray scattering and circular dichroism revealed that the parameters of the lipid mesophase can change upon peptide addition and that the peptide conformation is dependent on LCP characteristics such as hydrophobic mismatch, the putative lateral pressure profile, and the intrinsic surface curvature of each lipid system. Properties of electrode-supported lipid cubic mesophase films with embedded gramicidin were recently studied [153]. LCPs with embedded proteins can reveal fundamental biological processes and protein-lipid interactions $[135,150,154]$. They can also be used as a stable nanochannel network for protein chip development [155] or dispersed into nanoparticles such as lyotropic liquid crystalline drug/protein nanocarriers (cubosomes), as discussed in recent reviews $[156,157]$. LCP presents a new opportunity to study mitochondrial potassium 
channels; however, its future application requires overcoming several obstacles, including efficient synthesis and functional reconstitution of complex channel proteins.

\subsection{Solid-Supported and Tethered-Lipid Membranes}

Planar solid-supported lipid bilayers (s-PLBs) are model membranes formed on solid surfaces (Figure 5). Similar to PLBs, these structures have been developed as simplified lipid matrices for studies of membrane proteins to model their behavior in a reduced architecture. They provide a controlled environment for functional reconstitution and research on mitochondrial potassium channels. The choice of an electrode in the s-PLB technique usually depends on the signal being measured and the information to be obtained. As such, s-PLBs offer unique opportunities to use a variety of surface-sensitive techniques, particularly dynamic electrochemical techniques, to investigate the charge transfer and separation processes controlled by membrane proteins. In these techniques, the function of ion channels is synonymous with the detection of ion currents.

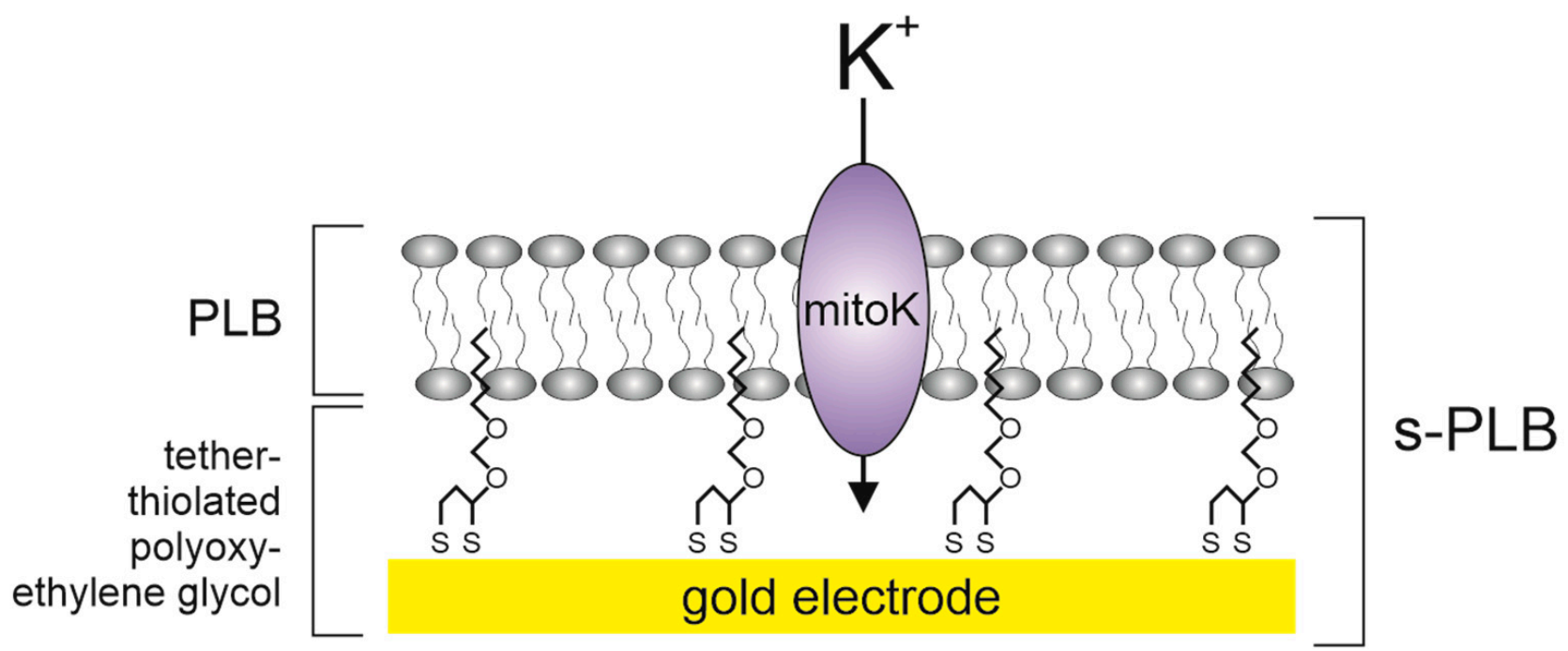

Figure 5. Solid supported membranes. Schematic drawing of the solid planar lipid bilayer s-PLB, showing the following parts: hydrophilic tether (e.g., thiol-derivatized polyoxyethylene glycol), providing covalent binding to the surface of gold, as well as an aqueous layer-a cushion-between the PLB and electrode; mitoK-potassium channel from the inner mitochondrial membrane; PLBplanar lipid bilayer. Please note that this scheme shows only one of the numerous possibilities of s-PLB deposition onto gold electrodes.

As described above, free-standing PLBs with large aqueous reservoirs on both sides allow for functional and biophysical studies of ion channels; however, they have the major disadvantage of being extremely fragile and susceptible to mechanical vibrations. Moreover, they have a relatively narrow potential window within which they remain relatively stable, typically up to $+/-100 \mathrm{mV}$. Depending on the lipid composition and PLB area, the so-called breakdown voltage is close to the limits of the accessible potential range. Therefore, studies on PLBs are limited to this narrow range. In contrast, the s-PLBs formed on metal electrodes allow for the use of a wide range of dynamic electrochemical techniques, including cyclic voltammetry, pulse/differential pulse voltammetry, differential capacitance, chronocoulometry, chronoamperometry, and electrochemical impedance spectroscopy (EIS). However, the major disadvantage of s-PLBs is that by depositing the lipid bilayer on the solid surface, the space available for ion flux between the electrode and the bilayer is reduced. Moreover, the membrane protein structure, particularly the hydrophilic part protruding from the bilayer, can be altered by contact with the metal surface. Therefore, the formation of s-PLBs suitable for membrane protein reconstitution, 
including mitochondrial potassium channels in a functionally active state, requires that these systems meet a number of criteria:

(a) They should be easily and reproducibly prepared and stable over time;

(b) They should have a lipid bilayer in the liquid crystalline state to allow lateral mobility;

(c) They should have a water reservoir (or, at the very least, a highly hydrated hydrophilic spacer region) between the electrode and the lipid bilayer.

Requirements (b) and (c) are necessary for the incorporation of membrane integral proteins into the lipid bilayer in a functionally active state.

Solid-supported PLBs can be prepared in a variety of ways, generally divided into two groups: bilayers that are physically (electrostatically) adsorbed on a functionalized electrode or chemically (covalently) bound to the surface via a tether chain that connects the lipids to the electrode. The latter case is depicted in Figure 5, with the tether being a polyoxyethylene hydrophilic chain modified on one end with thiol functionality for covalent attachment to metal (gold). The various modes of s-PLB formation are described in more detail in several publications [134,135,152,154] and are brilliantly summarized in the review work [158]. Apart from their stability, the s-PLBs also present another important advantage, which cannot be obtained with the free-standing PLB or patch-clamp technique. They offer the possibility of controlling the electric potential profile across the whole s-PLB. Therefore, it is possible to relate this profile to the protein ion-conducting behavior, including also quantitative identification of ion transfer steps along the channel [159-164]. As was already mentioned above, the use of thallium cations as $\mathrm{K}^{+}$surrogates appears to be especially useful in functional studies of potassium channels in whole mitochondria. Along this line, $\mathrm{Tl}^{+}$cations were used in the case of electrode-supported membrane systems to provide a quantitative model of the kinetics, dehydration-hydration, translocation, and charge transfer of this "surrogate" through gramicidin channels through the lipid monolayer deposited on the $\mathrm{Hg}$ electrode. The system stability enabled polarization of the monolayer even down to $-700 \mathrm{mV}$. This feature is necessary to utilize the redox behavior of the $\mathrm{Tl}^{+} / \mathrm{Tl}^{0}$ couple in chronoamperometric experiments, expanding the information gained from ionselective or indirect fluorescent probes. A polarization window larger than typically used in the patch-clamp or free-standing PLB system, and easily achievable in the case of s-PLB, also allows for the evaluation of the channel's conductivity profile $[159,160,165]$. Subsequent protein reconstitution into the s-PLBs can be achieved by using the methods typically used for free-standing PLBs, as described above. It is worth noting, however, that the possibility of controlling the polarization of the s-PLB system allows for increasing the effectiveness of channel reconstitution, as was shown in the case of gramicidin A. This feature could be explored in the reconstitution of mitochondrial channels.

This field of research is large and still growing, with studies of channel or poreforming peptides and proteins in which ion transfer is governed by a passive flux, as well as functional studies on membrane pumps, such as $\mathrm{Na}^{+} / \mathrm{K}^{+}$-ATPases, and proton-pumping ATPases $[166,167]$. It is worth noting that the use of s-PLBs enables the use of additional nonelectrochemical techniques, typically spectroscopic, to strengthen the conclusions drawn from electrochemical experiments. Surprisingly enough, despite many reports on the use of s-PLB in the electrophysiological studies of membrane channels and pumps, to the best of our knowledge, there have been no studies on mitochondrial potassium channels. We think that the use of such model membranes deposited on electrodes can greatly enlarge the information gathered with free-standing planar bilayer membranes. Due to their stability, s-PLBs allow for screening of a large library of ionic species, inhibitors/activators, and other molecules affecting the channel activity in a single set of experiments, using the same s-PLB $[158,168]$. Successful application of s-PLBs may facilitate studies of mitochondrial potassium channels.

\section{Final Remarks}

When compared to studies of plasma membrane channels, functional studies of mitochondrial $\mathrm{K}^{+}$channels present new experimental challenges and difficulties. In this review, 
we focused on experimental troubles and complications with the application of various techniques. We believe that this work will assist researchers in making informed decisions regarding which techniques should be used for optimal experiments, i.e., experiments measuring mitochondrial $\mathrm{K}^{+}$channel activity but not the traffic of other cations. Most likely, the key element of a successful experiment on a given mitochondrial $\mathrm{K}^{+}$channel is an approach that includes multiple techniques. This entails the parallel use of single-channel recordings by electrophysiological techniques and organellar/cellular flux techniques. The latter approach at the cellular level together with an array of biochemical techniques will also help to understand the physiological role of the interaction of mitochondrial $\mathrm{K}^{+}$ channels with other proteins.

What techniques do we lack in our methodological portfolio? What technique or techniques will be the most effective in the future? Single $\mathrm{K}^{+}$channel recordings that use patch-clamp or PLB techniques are likely to remain the gold standard in the future. This approach may be supported by new techniques based on solid-supported membranes and lipid cubic phases.

In particular, in our opinion, PLB techniques will see a resurgence in the near future. This is mainly because of the highest (compared to other methods) control of the $\mathrm{K}^{+}$channel reconstitution process in terms of protein channel subunits and the lipid environment. This kind of "experimental control" could be obtained by the application of in vitro translation and nanodisc technology. Additionally, parallel electrophysiological measurements in PLBs combined with single-molecule fluorescence microscopy and high-resolution fluorescence microscopy will add a new dimension to biophysical studies of mitochondrial $\mathrm{K}^{+}$channel function $[169,170]$.

However, credible techniques for measuring mitochondrial $\mathrm{K}^{+}$fluxes in situ, i.e., at the cellular, organ, or animal level, are still lacking. Here, new fluorescent $\mathrm{K}^{+}$sensing probes (small molecules or proteins) are likely to be used for these measurements. Because there are multiple $\mathrm{K}^{+}$transport pathways within mitochondria and cells, the parallel use of specific pharmacological drugs (potassium channel activators or inhibitors) will be required. Powerful chemical synthetic and genetic approaches will aid in solving these issues in the future.

Author Contributions: Conceptualization, A.S. (Adam Szewczyk) and P.K. (Piotr Koprowski); writing-original draft preparation, A.W., M.K., A.S. (Aleksandra Stefanowska), A.B., R.B., P.K. (Paweł Krysiński), A.S. (Adam Szewczyk) and P.K. (Piotr Koprowski); writing-review and editing, A.W., M.K., A.S. (Aleksandra Stefanowska), A.B., R.B., P.K. (Paweł Krysiński), A.S. (Adam Szewczyk) and P.K. (Piotr Koprowski); visualization, P.B.; funding acquisition, A.S. (Adam Szewczyk), P.K. (Piotr Koprowski), A.W. and M.K. All authors have read and agreed to the published version of the manuscript.

Funding: This research was funded by the Polish National Science Centre (grant Nos. 2018/31/N/ NZ1/00928 to A.W., 2020/37/N/NZ1/01808 to M.K., 2017/26/M/NZ3/00727 to P.K., and 2019/34/A/ NZ1/00352 to Szewczyk A.). This work was also implemented as a part of Operational Project Knowledge Education Development 2014-2020 co-financed by the European Social Fund, Project No. POWR.03.02.00-00-I007/16-00 (POWER 2014-2020) to Aleksandra Stefanowska and Aleksandra Buta.

Conflicts of Interest: The authors declare no conflict of interest.

\section{References}

1. Xu, H.; Martinoia, E.; Szabo, I. Organellar channels and transporters. Cell Calcium 2015, 58, 1-10. [CrossRef] [PubMed]

2. Li, B.; Gao, T. Functional Role of Mitochondrial and Nuclear BK Channels. Int. Rev. Neurobiol. 2016, 128, 163-191. [CrossRef] [PubMed]

3. Singh, H.; Stefani, E.; Toro, L. Intracellular BK(Ca) (iBK(Ca)) channels. J. Physiol. 2012, 590, 5937-5947. [CrossRef] [PubMed]

4. Cohen, S.; Valm, A.; Lippincott-Schwartz, J. Interacting organelles. Curr. Opin. Cell Biol. 2018, 53, 84-91. [CrossRef]

5. Peruzzo, R.; Biasutto, L.; Szabo, I.; Leanza, L. Impact of intracellular ion channels on cancer development and progression. Eur. Biophys. J. Biophys. Lett. 2016, 45, 685-707. [CrossRef] [PubMed]

6. Hausenloy, D.; Schulz, R.; Girao, H.; Kwak, B.; De Stefani, D.; Rizzuto, R.; Bernardi, P.; Di Lisa, F. Mitochondrial ion channels as targets for cardioprotection. J. Cell. Mol. Med. 2020, 24, 7102-7114. [CrossRef] [PubMed] 
7. Yu, J.; Yang, J. Ion channels as potential redox sensors in lysosomes. Channels 2019, 13, 477-482. [CrossRef]

8. Szewczyk, A.; Jarmuszkiewicz, W.; Kunz, W.S. Mitochondrial potassium channels. IUBMB Life 2009, 61, 134-143. [CrossRef]

9. Laskowski, M.; Augustynek, B.; Kulawiak, B.; Koprowski, P.; Bednarczyk, P.; Jarmuszkiewicz, W.; Szewczyk, A. What do we not know about mitochondrial potassium channels? Biochim. Biophys. Acta-Bioenerg. 2016, 1857, 1247-1257. [CrossRef]

10. Leanza, L.; Checchetto, V.; Biasutto, L.; Rossa, A.; Costa, R.; Bachmann, M.; Zoratti, M.; Szabo, I. Pharmacological modulation of mitochondrial ion channels. Br. J. Pharmacol. 2019, 176, 4258-4283. [CrossRef]

11. Olszewska, A.; Szewczyk, A. Mitochondria as a pharmacological target: Magnum overview. IUBMB Life 2013, 65, $273-281$. [CrossRef] [PubMed]

12. Wrzosek, A.; Augustynek, B.; Żochowska, M.; Szewczyk, A. Mitochondrial Potassium Channels as Druggable Targets. Biomolecules 2020, 10, 1200. [CrossRef] [PubMed]

13. Madeira, V. Overview of Mitochondrial Bioenergetics. Methods Mol. Biol. 2018, 1782, 1-6. [CrossRef] [PubMed]

14. Szabo, I.; Zoratti, M. Mitochondrial channels: Ion fluxes and more. Physiol. Rev. 2014, 94, 519-608. [CrossRef]

15. Vothknecht, U.; Szabo, I. Channels and transporters for inorganic ions in plant mitochondria: Prediction and facts. Mitochondrion 2020, 53, 224-233. [CrossRef]

16. Checchetto, V.; Szabo, I. Novel Channels of the Outer Membrane of Mitochondria: Recent Discoveries Change Our View. Bioessays 2018, 40, e1700232. [CrossRef]

17. Inoue, I.; Nagase, H.; Kishi, K.; Higuti, T. ATP-sensitive K+ channel in the mitochondrial inner membrane. Nature 1991, 352, 244-247. [CrossRef]

18. Paucek, P.; Mironova, G.; Mahdi, F.; Beavis, A.D.; Woldegiorgis, G.; Garlid, K.D. Reconstitution and partial purification of the glibenclamide-sensitive, ATP-dependent $\mathrm{K}+$ channel from rat liver and beef heart mitochondria. J. Biol. Chem. 1992, 267, 26062-26069. [CrossRef]

19. De Marchi, U.; Checchetto, V.; Zanetti, M.; Teardo, E.; Soccio, M.; Formentin, E.; Giacometti, G.M.; Pastore, D.; Zoratti, M.; Szabò, I. ATP-sensitive cation-channel in wheat (Triticum durum Desf.): Identification and characterization of a plant mitochondrial channel by patch-clamp. Cell. Physiol. Biochem. 2010, 26, 975-982. [CrossRef]

20. Choma, K.; Bednarczyk, P.; Koszela-Piotrowska, I.; Kulawiak, B.; Kudin, A.; Kunz, W.S.; Dołowy, K.; Szewczyk, A. Single channel studies of the ATP-regulated potassium channel in brain mitochondria. J. Bioenerg. Biomembr. 2009, 41, 323-334. [CrossRef]

21. Siemen, D.; Loupatatzis, C.; Borecky, J.; Gulbins, E.; Lang, F. Ca ${ }^{2+}$-activated K channel of the BK-type in the inner mitochondrial membrane of a human glioma cell line. Biochem. Biophys. Res. Commun. 1999, 257, 549-554. [CrossRef] [PubMed]

22. Koszela-Piotrowska, I.; Matkovic, K.; Szewczyk, A.; Jarmuszkiewicz, W. A large-conductance calcium-activated potassium channel in potato (Solanum tuberosum) tuber mitochondria. Biochem. J. 2009, 424, 307-316. [CrossRef] [PubMed]

23. Bednarczyk, P.; Koziel, A.; Jarmuszkiewicz, W.; Szewczyk, A. Large-conductance $\mathrm{Ca}^{2+}$-activated potassium channel in mitochondria of endothelial EA.hy926 cells. Am. J. Physiol. Circ. Physiol. 2013, 304, H1415-H1427. [CrossRef] [PubMed]

24. De Marchi, U.; Sassi, N.; Fioretti, B.; Catacuzzeno, L.; Cereghetti, G.M.; Szabò, I.; Zoratti, M.; Szabo, I.; Zoratti, M. Intermediate conductance $\mathrm{Ca}^{2+}$-activated potassium channel $(\mathrm{K}(\mathrm{Ca}) 3.1)$ in the inner mitochondrial membrane of human colon cancer cells. Cell Calcium 2009, 45, 509-516. [CrossRef] [PubMed]

25. Sassi, N.; De Marchi, U.; Fioretti, B.; Biasutto, L.; Gulbins, E.; Franciolini, F.; Szabò, I.; Zoratti, M. An investigation of the occurrence and properties of the mitochondrial intermediate-conductance $\mathrm{Ca}^{2+}$-activated $\mathrm{K}^{+}$channel mtKCa3.1. Biochim. Biophys. Acta-Bioenerg. 2010, 1797, 1260-1267. [CrossRef] [PubMed]

26. Stowe, D.F.; Gadicherla, A.K.; Zhou, Y.; Aldakkak, M.; Cheng, Q.; Kwok, W.-M.; Jiang, M.T.; Heisner, J.S.; Yang, M.; Camara, A.K.S. Protection against cardiac injury by small $\mathrm{Ca}^{2+}$-sensitive $\mathrm{K}^{+}$channels identified in guinea pig cardiac inner mitochondrial membrane. Biochim. Biophys. Acta-Biomembr. 2013, 1828, 427-442. [CrossRef]

27. Yang, M.; Camara, A.K.S.; Aldakkak, M.; Kwok, W.-M.; Stowe, D.F. Identity and function of a cardiac mitochondrial small conductance $\mathrm{Ca}^{2+}$-activated $\mathrm{K}^{+}$channel splice variant. Biochim. Biophys. Acta-Bioenerg. 2017, 1858, 442-458. [CrossRef]

28. Smith, C.; Wang, Y.; Nadtochiy, S.; Miller, J.; Jonas, E.; Dirksen, R.; Nehrke, K.; Brookes, P. Cardiac metabolic effects of K Na 1.2 channel deletion and evidence for its mitochondrial localization. FASEB J. 2018, 32, 6135-6149. [CrossRef]

29. Szabò, I.; Bock, J.; Jekle, A.; Soddemann, M.; Adams, C.; Lang, F.; Zoratti, M.; Gulbins, E. A novel potassium channel in lymphocyte mitochondria. J. Biol. Chem. 2005, 280, 12790-12798. [CrossRef]

30. Testai, L.; Barrese, V.; Soldovieri, M.V.; Ambrosino, P.; Martelli, A.; Vinciguerra, I.; Miceli, F.; Greenwood, I.A.; Curtis, M.J.; Breschi, M.C.; et al. Expression and function of Kv7.4 channels in rat cardiac mitochondria: Possible targets for cardioprotection. Cardiovasc. Res. 2016, 110, 40-50. [CrossRef] [PubMed]

31. Rusznák, Z.; Bakondi, G.; Kosztka, L.; Pocsai, K.; Dienes, B.; Fodor, J.; Telek, A.; Gönczi, M.; Szucs, G.; Csernoch, L. Mitochondrial expression of the two-pore domain TASK-3 channels in malignantly transformed and non-malignant human cells. Virchows Arch. 2008, 452, 415-426. [CrossRef] [PubMed]

32. Yu, Y.; He, H.; Kang, C.; Hu, K. TASK-1 regulates mitochondrial function under hypoxia. Biochem. Biophys. Res. Commun. 2021, 578, 163-169. [CrossRef] [PubMed]

33. Szabo, I.; Leanza, L.; Gulbins, E.; Zoratti, M. Physiology of potassium channels in the inner membrane of mitochondria. Pflugers Arch. J. Physiol. 2012, 463, 231-246. [CrossRef] [PubMed]

34. Rotko, D.; Bednarczyk, P.; Koprowski, P.; Kunz, W.S.; Szewczyk, A.; Kulawiak, B. Heme is required for carbon monoxide activation of mitochondrial BKCa channel. Eur. J. Pharmacol. 2020, 881. [CrossRef] [PubMed] 
35. Checchetto, V.; Leanza, L.; De Stefani, D.; Rizzuto, R.; Gulbins, E.; Szabo, I. Mitochondrial $\mathrm{K}^{+}$channels and their implications for disease mechanisms. Pharmacol. Ther. 2021, 227, 107874. [CrossRef] [PubMed]

36. Paggio, A.; Checchetto, V.; Campo, A.; Menabò, R.; Di Marco, G.; Di Lisa, F.; Szabo, I.; Rizzuto, R.; De Stefani, D. Identification of an ATP-sensitive potassium channel in mitochondria. Nature 2019, 572, 609-613. [CrossRef] [PubMed]

37. Singh, H.; Lu, R.; Bopassa, J.C.; Meredith, A.L.; Stefani, E.; Toro, L. mitoBKCa is encoded by the Kcnma1 gene, and a splicing sequence defines its mitochondrial location. Proc. Natl. Acad. Sci. USA 2013, 110, 10836. [CrossRef]

38. Bednarczyk, P.; Wieckowski, M.R.; Broszkiewicz, M.; Skowronek, K.; Siemen, D.; Szewczyk, A. Putative Structural and Functional Coupling of the Mitochondrial BKCa Channel to the Respiratory Chain. PLoS ONE 2013, 8, e68125. [CrossRef]

39. Szewczyk, A.; Skalska, J.; Głab, M.; Kulawiak, B.; Malińska, D.; Koszela-Piotrowska, I.; Kunz, W.S. Mitochondrial potassium channels: From pharmacology to function. Biochim. Biophys. Acta-Bioenerg. 2006, 1757, 715-720. [CrossRef]

40. Szewczyk, A.; Kajma, A.; Malinska, D.; Wrzosek, A.; Bednarczyk, P.; Zabłocka, B.; Dołowy, K. Pharmacology of mitochondrial potassium channels: Dark side of the field. FEBS Lett. 2010, 584, 2063-2069. [CrossRef]

41. Augustynek, B.; Kunz, W.S.; Szewczyk, A. Guide to the Pharmacology of Mitochondrial Potassium Channels. Handb. Exp. Pharmacol. 2016, 240, 103-127. [CrossRef]

42. Castrejón, V.; Peña, A.; Peña, P.; Uribe, S. Closure of the Yeast Mitochondria Unspecific Channel (YMUC) Unmasks a Mg ${ }^{2+}$ and Quinine Sensitive $\mathrm{K}^{+}$Uptake Pathway in Saccharomyces cerevisiae. J. Bioenerg. Biomembr. 2002, 34, 299-306. [CrossRef] [PubMed]

43. Lobanov, N.A.; Szewczyk, A.; Nowotny, M.; Nal, M.J.; Wójcik, G.; Nowotny, M.; Nałęcz, M.J. Effects of K+ channel inhibitors on potassium transport in bovine adrenal chromaffin granules. Biochem. End Mol. Biol. 1997, 41, 679-686. [CrossRef] [PubMed]

44. Zakharian, E. Ion channel reconstitution in lipid bilayers. Methods Enzymol. 2021, 652, 273-291. [CrossRef] [PubMed]

45. Kulawiak, B.; Bednarczyk, P. Reconstitution of brain mitochondria inner membrane into planar lipid bilayer. Acta. Neurobiol. Exp. 2005, 65, 271-276.

46. Bednarczyk, P.; Dołowy, K.; Szewczyk, A. Matrix $\mathrm{Mg}^{2+}$ regulates mitochondrial ATP-dependent potassium channel from heart. FEBS Lett. 2005, 579, 1625-1632. [CrossRef] [PubMed]

47. Bednarczyk, P.; Kicińska, A.; Kominkova, V.; Ondrias, K.; Dolowy, K.; Szewczyk, A. Quinine inhibits mitochondrial ATP-regulated potassium channel from bovine heart. J. Membr. Biol. 2004, 199, 63-72. [CrossRef]

48. Bednarczyk, P.; Dołowy, K.; Szewczyk, A. New properties of mitochondrial ATP-regulated potassium channels. J. Bioenerg. Biomembr. 2008, 40, 325-335. [CrossRef]

49. Jiang, M.T.; Ljubkovic, M.; Nakae, Y.; Shi, Y.; Kwok, W.M.; Stowe, D.F.; Bosnjak, Z.J. Characterization of human cardiac mitochondrial ATP-sensitive potassium channel and its regulation by phorbol ester in vitro. Am. J. Physiol. Heart Circ. Physiol. 2006, 290, H1770-H1776. [CrossRef]

50. Krajewska, M.; Koprowski, P. Solubilization, purification, and functional reconstitution of human ROMK potassium channel in copolymer styrene-maleic acid (SMA) nanodiscs. Biochim. Biophys. Acta-Biomembr. 2021, 1863. [CrossRef]

51. Petronilli, V.; Szabò, I.; Zoratti, M. The inner mitochondrial membrane contains ion-conducting channels similar to those found in bacteria. FEBS Lett. 1989, 259, 137-143. [CrossRef]

52. Sek, A.; Kampa, R.P.; Kulawiak, B.; Szewczyk, A.; Bednarczyk, P. molecules Identification of the Large-Conductance Ca ${ }^{2+}$ Regulated Potassium Channel in Mitochondria of Human Bronchial Epithelial Cells. Molecules 2021, 26, 3233. [CrossRef] [PubMed]

53. Bednarczyk, P.; Kicinska, A.; Laskowski, M.; Kulawiak, B.; Kampa, R.; Walewska, A.; Krajewska, M.; Jarmuszkiewicz, W.; Szewczyk, A. Evidence for a mitochondrial ATP-regulated potassium channel in human dermal fibroblasts. Biochim. Biophys. Acta-Bioenerg. 2018, 1859, 309-318. [CrossRef] [PubMed]

54. Frankenreiter, S.; Bednarczyk, P.; Kniess, A.; Bork, N.I.; Straubinger, J.; Koprowski, P.; Wrzosek, A.; Mohr, E.; Logan, A.; Murphy, M.P.; et al. cGMP-Elevating Compounds and Ischemic Conditioning Provide Cardioprotection Against Ischemia and Reperfusion Injury via Cardiomyocyte-Specific BK Channels. Circulation 2017, 136, 2337-2355. [CrossRef]

55. Toczyłowska-Mamińska, R.; Olszewska, A.; Laskowski, M.; Bednarczyk, P.; Skowronek, K.; Szewczyk, A. Potassium channel in the mitochondria of human keratinocytes. J. Investig. Dermatol. 2014, 134, 764-772. [CrossRef]

56. Laskowski, M.; Augustynek, B.; Bednarczyk, P.; Żochowska, M.; Kalisz, J.; O'rourke, B.; Szewczyk, A.; Kulawiak, B. Single-channel properties of the ROMK-pore-forming subunit of the mitochondrial ATP-sensitive potassium channel. Int. J. Mol. Sci. 2019, 20, 5323. [CrossRef]

57. Dahlem, Y.A.; Horn, T.F.; Buntinas, L.; Gonoi, T.; Wolf, G.; Siemen, D. The human mitochondrial KATP channel is modulated by calcium and nitric oxide: A patch-clamp approach. Biochim. Biophys. Acta-Bioenerg. 2004, 1656, 46-56. [CrossRef]

58. Yin, J.; Hu, Y.; Yoon, J. Fluorescent probes and bioimaging: Alkali metals, alkaline earth metals and pH. Chem. Soc. Rev. 2015, 44, 4619-4644. [CrossRef]

59. Sambath, K.; Liu, X.; Wan, Z.; Hutnik, L.; Belfield, K.D.; Zhang, Y. Potassium Ion Fluorescence Probes: Structures, Properties and Bioimaging. ChemPhotoChem 2021, 5, 317-325. [CrossRef]

60. Jezek, P.; Mahdi, F.; Garlid, K.D. Reconstitution of the beef heart and rat liver mitochondrial $\mathrm{K}^{+} / \mathrm{H}^{+}\left(\mathrm{Na}^{+} / \mathrm{H}^{+}\right)$antiporter. Quantitation of $\mathrm{K}^{+}$transport with the novel fluorescent probe, PBFI. J. Biol. Chem. 1990, 265, 10522-10526. [CrossRef]

61. Rimmele, T.S.; Chatton, J.Y. A novel optical intracellular imaging approach for potassium dynamics in astrocytes. PLoS ONE 2014, 9, e109243. [CrossRef] [PubMed] 
62. Garlid, K.D.; Paucek, P.; Yarov-Yarovoy, V.; Sun, X.; Schindler, P.A. The mitochondrial KATP channel as a receptor for potassium channel openers. J. Biol. Chem. 1996, 271, 8796-8799. [CrossRef] [PubMed]

63. Aon, M.A.; Cortassa, S.; Wei, A.C.; Grunnet, M.; O’Rourke, B. Energetic performance is improved by specific activation of $\mathrm{K}^{+}$ fluxes through KCa channels in heart mitochondria. Biochim. Biophys. Acta-Bioenerg. 2010, 1797, 71-80. [CrossRef] [PubMed]

64. Zoeteweij, J.P.; Van De Water, B.; De Bont, H.J.; Nagelkerke, J.F. Mitochondrial K+ as modulator of Ca(2+)-dependent cytotoxicity in hepatocytes. Novel application of the $\mathrm{K}(+)$-sensitive dye PBFI $(\mathrm{K}(+)$-binding benzofuran isophthalate) to assess free mitochondrial K+ concentrations. Biochem. J. 1994, 299 Pt 2, 539-543. [CrossRef]

65. Weaver, C.D.; Harden, D.; Dworetzky, S.I.; Robertson, B.; Knox, R.J. A Thallium-Sensitive, Fluorescence-Based Assay for Detecting and Characterizing Potassium Channel Modulators in Mammalian Cells. J. Biomol. Screen. 2016, 9, 671-677. [CrossRef]

66. Wojtovich, A.P.; Williams, D.M.; Karcz, M.K.; Lopes, C.M.B.; Gray, D.A.; Nehrke, K.W.; Brookes, P.S. A Novel Mitochondrial KATP Channel Assay. Circ. Res. 2010, 106, 1190-1196. [CrossRef]

67. Wojtovich, A.P.; Sherman, T.A.; Nadtochiy, S.M.; Urciuoli, W.R.; Brookes, P.S.; Nehrke, K. Slo-2 is cytoprotective and contributes to mitochondrial potassium transport. PLoS ONE 2011, 6, e28287. [CrossRef]

68. Foster, D.B.; Ho, A.S.; Rucker, J.; Garlid, A.O.; Chen, L.; Sidor, A.; Garlid, K.D.; O’Rourke, B. Mitochondrial ROMK Channel Is a Molecular Component of MitoK(ATP). Circ. Res. 2012, 111, 446-454. [CrossRef]

69. Lewis, L.; Bhave, G.; Chauder, B.; Banerjee, S.; Lornsen, K.; Redha, R.; Fallen, K.; Lindsley, C.; Weaver, C.; Denton, J. Highthroughput screening reveals a small-molecule inhibitor of the renal outer medullary potassium channel and Kir7.1. Mol. Pharmacol. 2009, 76, 1094-1103. [CrossRef]

70. Beacham, D.W.; Blackmer, T.; Grady, M.O.; Hanson, G.T. Cell-Based Potassium Ion Channel Screening Using the FluxOR ${ }^{\mathrm{TM}}$ Assay. J. Biomol. Screen. 2010, 15, 441-446. [CrossRef]

71. Bischof, H.; Rehberg, M.; Stryeck, S.; Artinger, K.; Eroglu, E.; Waldeck-Weiermair, M.; Gottschalk, B.; Rost, R.; Deak, A.T.; Niedrist, T.; et al. Novel genetically encoded fluorescent probes enable real-time detection of potassium in vitro and in vivo. Nat. Commun. 2017, 8, 1-12. [CrossRef] [PubMed]

72. Bajgar, R.; Seetharaman, S.; Kowaltowski, A.J.; Garlid, K.D.; Paucek, P. Identification and properties of a novel intracellular (mitochondrial) ATP-sensitive potassium channel in brain. J. Biol. Chem. 2001, 276, 33369-33374. [CrossRef]

73. Costa, A.D.T.; Garlid, K.D. Intramitochondrial signaling: Interactions among mitoKATP, PKCE, ROS, and MPT. Am. J. Physiol. Circ. Physiol. 2008, 295, 874-882. [CrossRef] [PubMed]

74. Kicinska, A.; Augustynek, B.; Kulawiak, B.; Jarmuszkiewicz, W.; Szewczyk, A.; Bednarczyk, P. A large-conductance calciumregulated $\mathrm{K}+$ channel in human dermal fibroblast mitochondria. Biochem. J. 2016, 473, 4457-4471. [CrossRef] [PubMed]

75. Kicinska, A.; Swida, A.; Bednarczyk, P.; Koszela-Piotrowska, I.; Choma, K.; Dolowy, K.; Szewczyk, A.; Jarmuszkiewicz, W. ATP-sensitive potassium channel in mitochondria of the eukaryotic microorganism Acanthamoeba castellanii. J. Biol. Chem. 2007, 282, 17433-17441. [CrossRef]

76. Laskowski, M.; Kicinska, A.; Szewczyk, A.; Jarmuszkiewicz, W. Mitochondrial large-conductance potassium channel from Dictyostelium discoideum. Int. J. Biochem. Cell Biol. 2015, 60, 167-175. [CrossRef] [PubMed]

77. Dolga, A.M.; Netter, M.F.; Perocchi, F.; Doti, N.; Meissner, L.; Tobaben, S.; Grohm, J.; Zischka, H.; Plesnila, N.; Decher, N.; et al. Mitochondrial small conductance sk2 channels prevent glutamate-induced oxytosis and mitochondrial dysfunction. J. Biol. Chem. 2013, 288, 10792-10804. [CrossRef] [PubMed]

78. Mueller, P.; Rudin, D.O.; Ti Tien, H.; Wescott, W.C. Reconstitution of Cell Membrane Structure in vitro and its Transformation into an Excitable System. Nature 1962, 194, 979-980. [CrossRef]

79. Daum, G.; Vance, J.E. Import of lipids into mitochondria. Prog. Lipid Res. 1997, 36, 103-130. [CrossRef]

80. Urbani, A.; Giorgio, V.; Carrer, A.; Franchin, C.; Arrigoni, G.; Jiko, C.; Abe, K.; Maeda, S.; Shinzawa-Itoh, K.; Bogers, J.; et al. Purified F-ATP synthase forms a $\mathrm{Ca}^{2+}$-dependent high-conductance channel matching the mitochondrial permeability transition pore. Nat. Commun. 2019, 10, 4341. [CrossRef]

81. Mnatsakanyan, N.; Llaguno, M.C.; Yang, Y.; Yan, Y.; Weber, J.; Sigworth, F.J.; Jonas, E.A. A mitochondrial megachannel resides in monomeric F1FO ATP synthase. Nat. Commun. 2019, 10, 5823. [CrossRef] [PubMed]

82. Overduin, M.; Esmaili, M. Memtein: The fundamental unit of membrane-protein structure and function. Chem. Phys. Lipids 2019, 218, 73-84. [CrossRef] [PubMed]

83. Denisov, I.G.; Grinkova, Y.V.; Lazarides, A.A.; Sligar, S.G. Directed Self-Assembly of Monodisperse Phospholipid Bilayer Nanodiscs with Controlled Size. J. Am. Chem. Soc. 2004, 126, 3477-3487. [CrossRef] [PubMed]

84. Dörr, J.M.; Scheidelaar, S.; Koorengevel, M.C.; Dominguez, J.J.; Schäfer, M.; van Walree, C.A.; Killian, J.A. The styrene-maleic acid copolymer: A versatile tool in membrane research. Eur. Biophys. J. 2016, 45, 3-21. [CrossRef] [PubMed]

85. Carlson, M.L.; Young, J.W.; Zhao, Z.; Fabre, L.; Jun, D.; Li, J.; Li, J.; Dhupar, H.S.; Wason, I.; Mills, A.T.; et al. The peptidisc, a simple method for stabilizing membrane proteins in detergent-free solution. eLife 2018, 7, e34085. [CrossRef] [PubMed]

86. Angiulli, G.; Dhupar, H.; Suzuki, H.; Wason, I.; Van Hoa, F.D.; Walz, T. New approach for membrane protein reconstitution into peptidiscs and basis for their adaptability to different proteins. eLife 2020, 9, e53530. [CrossRef]

87. Bao, H.; Duong, F.; Chan, C. A step-by-step method for the reconstitution of an ABC transporter into nanodisc lipid particles. J. Vis. Exp. 2012, 66, e3910. [CrossRef]

88. Winterstein, L.L.M.; Kukovetz, K.; Rauh, O.; Turman, D.L.D.; Braun, C.; Moroni, A.; Schroeder, I.; Thiel, G. Reconstitution and functional characterization of ion channels from nanodiscs in lipid bilayers. J. Gen. Physiol. 2018, 150, 637-646. [CrossRef] 
89. Overduin, M.; Esmaili, M. Native Nanodiscs and the Convergence of Lipidomics, Metabolomics, Interactomics and Proteomics. Appl. Sci. 2019, 9, 1230. [CrossRef]

90. Smirnova, I.A.; Sjöstrand, D.; Li, F.; Björck, M.; Schäfer, J.; Östbye, H.; Högbom, M.; von Ballmoos, C.; Lander, G.C.; Ädelroth, P.; et al. Isolation of yeast complex IV in native lipid nanodiscs. Biochim. Biophys. Acta-Biomembr. 2016, 1858, $2984-2992$. [CrossRef]

91. Janson, K.; Zierath, J.; Kyrilis, F.L.; Semchonok, D.A.; Hamdi, F.; Skalidis, I.; Kopf, A.H.; Das, M.; Kolar, C.; Rasche, M.; et al. Solubilization of artificial mitochondrial membranes by amphiphilic copolymers of different charge. Biochim. Biophys. ActaBiomembr. 2021, 1863, 183725. [CrossRef]

92. Neher, E.; Sakmann, B. Single-channel currents recorded from membrane of denervated frog muscle fibres. Nature 1976, 260, 799-802. [CrossRef] [PubMed]

93. Neher, E.; Sakmann, B.; Steinbach, J.H. The extracellular patch clamp: A method for resolving currents through individual open channels in biological membranes. Pflügers Arch. Eur. J. Physiol. 1978, 375, 219-228. [CrossRef] [PubMed]

94. Segev, A.; Garcia-Oscos, F.; Kourrich, S. Whole-cell Patch-clamp Recordings in Brain Slices. J. Vis. Exp 2016, 112, e54024. [CrossRef] [PubMed]

95. Cao, Q.; Zhong, X.Z.; Zou, Y.; Zhang, Z.; Toro, L.; Dong, X.-P. BK Channels Alleviate Lysosomal Storage Diseases by Providing Positive Feedback Regulation of Lysosomal Ca ${ }^{2+}$ Release. Dev. Cell 2015, 33, 427-441. [CrossRef]

96. Feng, X.; Zhao, Z.; Li, Q.; Tan, Z. Lysosomal Potassium Channels: Potential Roles in Lysosomal Function and Neurodegenerative Diseases. CNS Neurol. Disord. Drug Targets 2018, 17, 261-266. [CrossRef]

97. Sorgato, M.C.; Keller, B.U.; Stühmer, W. Patch-clamping of the inner mitochondrial membrane reveals a voltage-dependent ion channel. Nature 1987, 330, 498-500. [CrossRef]

98. Bustamante, J.; Varanda, W. Patch-clamping macromolecular translocation along nuclear pores. Brazilian J. Med. Biol. Res. 1998, 31, 333-354. [CrossRef]

99. Mak, D.-O.D.; Vais, H.; Cheung, K.-H.; Foskett, J.K. Isolating Nuclei from Cultured Cells for Patch-Clamp Electrophysiology of Intracellular $\mathrm{Ca}^{2+}$ Channels. Cold Spring Harb. Protoc. 2013, 2013, 880-884. [CrossRef]

100. Martinac, B.; Buechner, M.; Delcour, A.H.; Adler, J.; Kung, C. Pressure -sensitive ion channel in Escherichia coli. Proc. Natl. Acad. Sci. USA 1987, 84, 2297-2301. [CrossRef]

101. Grajkowski, W.; Kubalski, A.; Koprowski, P. Surface changes of the mechanosensitive channel MscS upon its activation, inactivation, and closing. Biophys. J. 2005, 88, 3050-3059. [CrossRef] [PubMed]

102. Szabó, I.; Zoratti, M. The mitochondrial megachannel is the permeability transition pore. J. Bioenerg. Biomembr. 1992, 24, 111-117. [CrossRef] [PubMed]

103. Walewska, A.; Kulawiak, B.; Szewczyk, A.; Koprowski, P. Mechanosensitivity of mitochondrial large-conductance calciumactivated potassium channels. Biochim. Biophys. Acta-Bioenerg. 2018, 1859, 797-805. [CrossRef]

104. Kampa, R.P.; Kicinska, A.; Jarmuszkiewicz, W.; Pasikowska-Piwko, M.; Dolegowska, B.; Debowska, R.; Szewczyk, A.; Bednarczyk, P. Naringenin as an opener of mitochondrial potassium channels in dermal fibroblasts. Exp. Dermatol. 2019, 28, 543-550. [CrossRef] [PubMed]

105. Kampa, R.; Sęk, A.; Szewczyk, A.; Bednarczyk, P. Cytoprotective effects of the flavonoid quercetin by activating mitochondrial BK Ca channels in endothelial cells. Biomed. Pharmacother. 2021, 142, 112039. [CrossRef] [PubMed]

106. Jonas, E.A.; Knox, R.J.; Kaczmarek, L.K. Giga-Ohm Seals on Intracellular Membranes: A Technique for Studying Intracellular Ion Channels in Intact Cells. Neuron 1997, 19, 7-13. [CrossRef]

107. Jonas, E.A.; Mnatsakanyan, N. Examination of Mitochondrial Ion Conductance by Patch Clamp in Intact Neurons and Mitochondrial Membrane Preparations. Neuromethods 2017, 123, 211-238. [CrossRef]

108. Bednarczyk, P.; Kampa, R.P.; Gałecka, S.; Se, A.; Walewska, A.; Koprowski, P. Patch-Clamp Recording of the Activity of Ion Channels. In Mitochondrial Medicine; Springer: New York, NY, USA, 2021.

109. Kirichok, Y.; Krapivinsky, G.; Clapham, D.E. The mitochondrial calcium uniporter is a highly selective ion channel. Nature 2004, 427, 360-364. [CrossRef]

110. King, C.; Sengupta, P.; Seo, A.Y.; Lippincott-Schwartz, J. ER membranes exhibit phase behavior at sites of organelle contact. Proc. Natl. Acad. Sci. USA 2020, 117, 7225-7235. [CrossRef]

111. Jakob, R.; Beutner, G.; Sharma, V.K.; Duan, Y.; Gross, R.A.; Hurst, S.; Jhun, B.S.; O-Uchi, J.; Sheu, S.S. Molecular and functional identification of a mitochondrial ryanodine receptor in neurons. Neurosci. Lett. 2014, 575, 7-12. [CrossRef]

112. Ryu, S.Y.; Beutner, G.; Kinnally, K.W.; Dirksen, R.T.; Sheu, S.S. Single Channel Characterization of the Mitochondrial Ryanodine Receptor in Heart Mitoplasts. J. Biol. Chem. 2011, 286, 21324-21329. [CrossRef] [PubMed]

113. Noterman, M.F.; Chaubey, K.; Lin-Rahardja, K.; Rajadhyaksha, A.M.; Pieper, A.A.; Taylor, E.B. Dual-process brain mitochondria isolation preserves function and clarifies protein composition. Proc. Natl. Acad. Sci. USA 2021, 118, e2019046118. [CrossRef] [PubMed]

114. Garg, V.; Suzuki, J.; Paranjpe, I.; Unsulangi, T.; Boyman, L.; Milescu, L.; Lederer, W.; Kirichok, Y. The mechanism of MICUdependent gating of the mitochondrial $\mathrm{Ca}^{2+}$ uniporter. eLife 2021, 10, e69312. [CrossRef] [PubMed]

115. Szabó, I.; Bernardi, P.; Zoratti, M. Modulation of the mitochondrial megachannel by divalent cations and protons. J. Biol. Chem. 1992, 267, 2940-2946. [CrossRef] 
116. Martinucci, S.; Szabò, I.; Tombola, F.; Zoratti, M. Ca ${ }^{2+}$-reversible inhibition of the mitochondrial megachannel by ubiquinone analogues. FEBS Lett. 2000, 480, 89-94. [CrossRef]

117. Giorgio, V.; von Stockum, S.; Antoniel, M.; Fabbro, A.; Fogolari, F.; Forte, M.; Glick, G.D.; Petronilli, V.; Zoratti, M.; Szabó, I.; et al. Dimers of mitochondrial ATP synthase form the permeability transition pore. Proc. Natl. Acad. Sci. USA 2013, 110, 5887-5892. [CrossRef]

118. Carraro, M.; Carrer, A.; Urbani, A.; Bernardi, P. Molecular nature and regulation of the mitochondrial permeability transition pore(s), drug target(s) in cardioprotection. J. Mol. Cell. Cardiol. 2020, 144, 76-86. [CrossRef]

119. Kinnally, K.; Zorov, D.; Antonenko, Y.; Perini, S. Calcium modulation of mitochondrial inner membrane channel activity. Biochem. Biophys. Res. Commun. 1991, 176, 1183-1188. [CrossRef]

120. Linley, J. Perforated whole-cell patch-clamp recording. Methods Mol. Biol. 2013, 998, 149-157. [CrossRef]

121. Liu, D.; Slevin, J.R.; Lu, C.; Chan, S.L.; Hansson, M.; Elmér, E.; Mattson, M.P. Involvement of mitochondrial K+ release and cellular efflux in ischemic and apoptotic neuronal death. J. Neurochem. 2003, 86, 966-979. [CrossRef]

122. Kong, X.; Su, F.; Zhang, L.; Yaron, J.; Lee, F.; Shi, Z.; Tian, Y.; Meldrum, D.R. A Highly Selective Mitochondria-Targeting Fluorescent $\mathrm{K}^{+}$Sensor. Angew. Chemie Int. Ed. 2015, 54, 12053-12057. [CrossRef] [PubMed]

123. Ning, J.; Tian, Y. Development of a new simple mitochondria-targeted fluorescent $\mathrm{K}+$ sensor and the application in highthroughput monitoring K+ fluxes. Sens. Actuators B Chem. 2020, 307, 127659. [CrossRef]

124. Song, G.; Jiang, D.; Wang, L.; Ning, J.; Sun, X.; Su, F.; Chen, M.; Tian, Y. A mitochondria-targeting NIR fluorescent potassium ion sensor: Real-time investigation of the mitochondrial K+ regulation of apoptosis in situ. Chem. Commun. 2020, 56, 5405-5408. [CrossRef] [PubMed]

125. Hille, B. Potassium channels in myelinated nerve. Selective permeability to small cations. J. Gen. Physiol. 1973, 61, 669-686. [CrossRef] [PubMed]

126. Shen, Y.; Wu, S.; Rancic, V.; Aggarwal, A.; Qian, Y.; Miyashita, S.; Ballanyi, K.; Campbell, R.; Dong, M. Genetically encoded fluorescent indicators for imaging intracellular potassium ion concentration. Commun. Biol. 2019, 2, 18. [CrossRef] [PubMed]

127. Garlid, K.D.; Paucek, P. Mitochondrial potassium transport: The $\mathrm{K}^{+}$cycle. Biochim. Biophys. Acta-Bioenergetics 2003, $1606,23-41$. [CrossRef]

128. Nicholls, D.G.; Grav, H.J.; Lindberg, O. Mitochondria from Hamster Brown-Adipose Tissue. Eur. J. Biochem. 1972, 31, 526-533. [CrossRef]

129. Halestrap, A.P. The regulation of the matrix volume of mammalian mitochondria in vivo and in vitro and its role in the control of mitochondrial metabolism. Biochim. Biophys. Acta 1989, 973, 355-382. [CrossRef]

130. Riess, M.L.; Costa, A.D.; Carlson, R.; Garlid, K.D.; Heinen, A.; Stowe, D.F. Differential increase of mitochondrial matrix volume by sevoflurane in isolated cardiac mitochondria. Anesth. Analg. 2008, 106, 1049-1055. [CrossRef]

131. Javadov, S.; Chapa-Dubocq, X.; Makarov, V. Different approaches to modeling analysis of mitochondrial swelling. Mitochondrion 2018, 38, 58-70. [CrossRef]

132. Kulawiak, B.; Kudin, A.P.; Szewczyk, A.; Kunz, W.S. BK channel openers inhibit ROS production of isolated rat brain mitochondria. Exp. Neurol. 2008, 212, 543-547. [CrossRef] [PubMed]

133. Czyz, A.; Szewczyk, A.; Nalecz, M.J.; Wojtczak, L. The role of mitochondrial potassium fluxes in controlling the protonmotive force in energized mitochondria. Biochem. Biophys. Res. Commun. 1995, 210, 98-104. [CrossRef] [PubMed]

134. Höfer, N.; Aragão, D.; Caffrey, M. Crystallizing Transmembrane Peptides in Lipidic Mesophases. Biophys. J. 2010, 99, L23-L25. [CrossRef] [PubMed]

135. Nazaruk, E.; Bilewicz, R. Catalytic activity of oxidases hosted in lipidic cubic phases on electrodes. Bioelectrochemistry 2007, 71, 8-14. [CrossRef]

136. Landau, E.; Rosenbusch, J. Lipidic cubic phases: A novel concept for the crystallization of membrane proteins. Proc. Natl. Acad. Sci. USA 1996, 93, 14532-14535. [CrossRef]

137. Li, D.; Caffrey, M. Lipid cubic phase as a membrane mimetic for integral membrane protein enzymes. Proc. Natl. Acad. Sci. USA 2011, 108, 8639-8644. [CrossRef]

138. Caffrey, M. IUCr A comprehensive review of the lipid cubic phase or in meso method for crystallizing membrane and soluble proteins and complexes. Acta Crystallogr. Sect. F Struct. Biol. Commun. 2015, 71, 3-18. [CrossRef]

139. Tiefenbrunn, T.; Liu, W.; Chen, Y.; Katritch, V.; Stout, C.D.; Fee, J.A.; Cherezov, V. High Resolution Structure of the ba3 Cytochrome c Oxidase from Thermus thermophilus in a Lipidic Environment. PLoS ONE 2011, 6, e22348. [CrossRef]

140. Santos, J.S.; Asmar-Rovira, G.A.; Han, G.W.; Liu, W.; Syeda, R.; Cherezov, V.; Baker, K.A.; Stevens, R.C.; Montal, M. Crystal Structure of a Voltage-gated $\mathrm{K}^{+}$Channel Pore Module in a Closed State in Lipid Membranes. J. Biol. Chem. 2012, 287 , 43063-43070. [CrossRef]

141. Zabara, A.; Chong, J.T.Y.; Martiel, I.; Stark, L.; Cromer, B.A.; Speziale, C.; Drummond, C.J.; Mezzenga, R. Design of ultra-swollen lipidic mesophases for the crystallization of membrane proteins with large extracellular domains. Nat. Commun. 2018, 9, 1-9. [CrossRef]

142. Cherezov, V. Lipidic cubic phase technologies for membrane protein structural studies. Curr. Opin. Struct. Biol. 2011, 21, 559-566. [CrossRef] [PubMed]

143. Ma, P.; Weichert, D.; Aleksandrov, L.A.; Jensen, T.J.; Riordan, J.R.; Liu, X.; Kobilka, B.K.; Caffrey, M. The cubicon method for concentrating membrane proteins in the cubic mesophase. Nat. Protoc. 2017, 12, 1745-1762. [CrossRef] [PubMed] 
144. Belrhali, H.; Nollert, P.; Royant, A.; Menzel, C.; Rosenbusch, J.P.; Landau, E.M.; Pebay-Peyroula, E. Protein, lipid and water organization in bacteriorhodopsin crystals: A molecular view of the purple membrane at $1.9 \AA$ resolution. Structure 1999, 7, 909-917. [CrossRef]

145. Nazaruk, E.; Szlęzak, M.; Górecka, E.; Bilewicz, R.; Osornio, Y.M.; Uebelhart, P.; Landau, E.M. Design and Assembly of pH-Sensitive Lipidic Cubic Phase Matrices for Drug Release. Langmuir 2014, 30, 1383-1390. [CrossRef] [PubMed]

146. Sun, W.; Vallooran, J.J.; Fong, W.-K.; Mezzenga, R. Lyotropic Liquid Crystalline Cubic Phases as Versatile Host Matrices for Membrane-Bound Enzymes. J. Phys. Chem. Lett. 2016, 7, 1507-1512. [CrossRef] [PubMed]

147. Zatloukalová, M.; Nazaruk, E.; Novák, D.; Vacek, J.; Bilewicz, R. Lipidic liquid crystalline cubic phases for preparation of ATP-hydrolysing enzyme electrodes. Biosens. Bioelectron. 2018, 100, 437-444. [CrossRef]

148. Speziale, C.; Manni, L.S.; Manatschal, C.; Landau, E.M.; Mezzenga, R. A macroscopic $\mathrm{H}^{+}$and $\mathrm{Cl}^{-}$ions pump via reconstitution of EcClC membrane proteins in lipidic cubic mesophases. Proc. Natl. Acad. Sci. USA 2016, 113, 7491-7496. [CrossRef]

149. Speziale, C.; Zabara, A.F.; Drummond, C.J.; Mezzenga, R. Active Gating, Molecular Pumping, and Turnover Determination in Biomimetic Lipidic Cubic Mesophases with Reconstituted Membrane Proteins. ACS Nano 2017, 11, 11687-11693. [CrossRef]

150. Conn, C.E.; Drummond, C.J. Nanostructured bicontinuous cubic lipid self-assembly materials as matrices for protein encapsulation. Soft Matter 2013, 9, 3449-3464. [CrossRef]

151. Li, D.; Caffrey, M. Structure and Functional Characterization of Membrane Integral Proteins in the Lipid Cubic Phase. J. Mol. Biol. 2020, 432, 5104-5123. [CrossRef]

152. Meikle, T.G.; Conn, C.E.; Separovic, F.; Drummond, C.J. Exploring the structural relationship between encapsulated antimicrobial peptides and the bilayer membrane mimetic lipidic cubic phase: Studies with gramicidin A'. RSC Adv. 2016, 6, 68685-68694. [CrossRef]

153. Buta, A.; Nazaruk, E.; Dziubak, D.; Szewczyk, A.; Bilewicz, R. Properties of electrode-supported lipid cubic mesophase films with embedded gramicidin A: Structure and ion-transport studies. Bioelectrochemistry 2022, 144, 108042. [CrossRef] [PubMed]

154. Nazaruk, E.; Michota, A.; Bukowska, J.; Shleev, S.; Gorton, L.; Bilewicz, R. Properties of native and hydrophobic laccases immobilized in the liquid-crystalline cubic phase on electrodes. JBIC J. Biol. Inorg. Chem. 2006, 12, 335-344. [CrossRef]

155. Angelova, A.; Ollivon, M.; Campitelli, A.; Bourgaux, C. Lipid Cubic Phases as Stable Nanochannel Network Structures for Protein Biochip Development: X-ray Diffraction Study. Langmuir 2003, 19, 6928-6935. [CrossRef]

156. Murgia, S.; Biffi, S.; Mezzenga, R. Recent advances of non-lamellar lyotropic liquid crystalline nanoparticles in nanomedicine. Curr. Opin. Colloid Interface Sci. 2020, 48, 28-39. [CrossRef]

157. Tenchov, R.; Bird, R.; Curtze, A.E.; Zhou, Q. Lipid Nanoparticles-From Liposomes to mRNA Vaccine Delivery, a Landscape of Research Diversity and Advancement. ACS Nano 2021, 15, 16982-17015. [CrossRef]

158. Guidelli, R.; Becucci, L. Functional activity of peptide ion channels in tethered bilayer lipid membranes: Review. Electrochem. Sci. Adv. 2021, e2100180. [CrossRef]

159. Becucci, L.; Guidelli, R. Equilibrium distribution of $\mathrm{K}+$ ions in the hydrophilic spacer of tethered bilayer lipid membranes. Soft Matter 2009, 5, 2294-2301. [CrossRef]

160. Becucci, L.; Moncelli, M.R.; Guidelli, R. Thallous ion movements through gramicidin channels incorporated in lipid monolayers supported by mercury. Biophys. J. 2002, 82, 852. [CrossRef]

161. Su, Z.F.; Leitch, J.J.; Lipkowski, J. Electrode-supported biomimetic membranes: An electrochemical and surface science approach for characterizing biological cell membranes. Curr. Opin. Electrochem. 2018, 12, 60-72. [CrossRef]

162. Su, Z.F.; Goodall, B.; Leitch, J.J.; Lipkowski, J. Ion transport mechanism in gramicidin A channels formed in floating bilayer lipid membranes supported on gold electrodes. Electrochim. Acta 2021, 375, 137892. [CrossRef]

163. Guidelli, R.; Becucci, L. 4 Electrochemistry of Biomimetic Membranes. In Applications of Electrochemistry and Nanotechnology in Biology and Medicine II; Springer: Boston, MA, USA, 2012; pp. 147-266. [CrossRef]

164. Brzozowska, M.; Oberts, B.P.; Blanchard, G.J.; Majewski, J.; Krysinski, P. Design and Characterization of Novel Tether Layer for Coupling of a Bilayer Lipid Membrane to the Surface of Gold. Langmuir 2009, 25, 9337-9345. [CrossRef]

165. Mauzeroll, J.; Buda, M.; Bard, A.J.; Prieto, F.; Rueda, M. Detection of Tl(I) transport through a gramicidin-dioleoyl phosphatidylcholine monolayer using the substrate generation-tip collection mode of scanning electrochemical microscopy. Langmuir 2002, 18, 9453-9461. [CrossRef]

166. Zebrowska, A.; Krysiński, P. Incorporation of $\mathrm{Na}^{+}, \mathrm{K}^{+}$-ATP-ase into the Thiolipid Biomimetic Assemblies via the Fusion of Proteoliposomes. Langmuir 2004, 20, 11127-11133. [CrossRef] [PubMed]

167. Naumann, R.; Baumgart, T.; Gräber, P.; Jonczyk, A.; Offenhäusser, A.; Knoll, W. Proton transport through a peptide-tethered bilayer lipid membrane by the H+-ATP synthase from chloroplasts measured by impedance spectroscopy. Biosens. Bioelectron. 2002, 17, 25-34. [CrossRef]

168. Knoll, W.; Naumann, R.; Friedrich, M.; Robertson, J.W.F.; Lösche, M.; Heinrich, F.; McGillivray, D.J.; Schuster, B.; Gufler, P.C.; Pum, D.; et al. Solid supported lipid membranes: New concepts for the biomimetic functionalization of solid surfaces. Biointerphases 2008, 3, FA125. [CrossRef] [PubMed]

169. Bartsch, P.; Walter, C.; Selenschik, P.; Honigmann, A.; Wagner, R. Horizontal Bilayer for Electrical and Optical Recordings. Materials 2012, 5, 2705. [CrossRef]

170. Rajapaksha, S.P.; Wang, X.; Lu, H.P. Suspended Lipid Bilayer for Optical and Electrical Measurements of Single Ion Channel Proteins. Anal. Chem. 2013, 85, 8951-8955. [CrossRef] 